diastereoisomers; mp about $200^{\circ} \mathrm{C}$; ${ }^{31} \mathrm{P}$ NMR (THF) $\delta 67.2$ and 67.7; ${ }^{1} \mathrm{H} \mathrm{NMR}\left(\mathrm{CDCl}_{3}\right) \delta 1.96\left(\mathrm{~m},{ }^{6} J_{\mathrm{HH}}=0.5,1.35 \mathrm{H}, \mathrm{C}_{3}-\mathrm{CH}_{3} \mathrm{~A}\right.$ isomer), $2.03\left(\mathrm{~m},{ }^{b} J_{\mathrm{HH}}=0.5,1.65 \mathrm{H}, \mathrm{C}_{3}-\mathrm{CH}_{3} \mathrm{~B}\right.$ isomer $), 2.12(\mathrm{~m}$, $\left.4 J_{\mathrm{HP}}=1.7\right)$ and $2.15\left(\mathrm{~m},{ }^{4} J_{\mathrm{HP}}=1.7,3 \mathrm{H} ; \mathrm{C}_{4}-\mathrm{CH}_{3} \mathrm{~A}\right.$ and $\left.\mathrm{B}\right), 2.27$ $\left(\mathrm{d},{ }^{2} J_{\mathrm{HP}}=14.6,1.65 \mathrm{H}, \mathrm{SCH}_{3} \mathrm{~B}\right), 2.37\left(\mathrm{~d},{ }^{2} J_{\mathrm{HP}}=14.9,1.35 \mathrm{H}\right.$, $\left.\mathrm{SCH}_{3} \mathrm{~A}\right), 6.02\left(\mathrm{dm},{ }^{2} J_{\mathrm{HP}}=33.5,{ }^{5} J_{\mathrm{HH}}=0.5,0.55, \mathrm{C}_{5}-\mathrm{H} \mathrm{B}\right), 6.14$ $\left(\mathrm{dm},{ }^{2} J_{\mathrm{HP}}=33.4,0.45 \mathrm{H}, \mathrm{C}_{5}-\mathrm{H} \mathrm{A}\right) ;{ }^{13} \mathrm{C} \mathrm{NMR}$ selected data $\left(\mathrm{CDCl}_{3}\right)$ $\delta 13.08\left(\mathrm{~s}, \mathrm{CH}_{3}\right), 15.21\left(\mathrm{~d},{ }^{2} J=14.1\right)$ and $17.46\left(\mathrm{~d},{ }^{2} J=18.1, \mathrm{SCH}_{3}\right.$ $A$ and $B$ ), 125.02 (pseudo $\left.t,{ }^{2} J=84.4, C_{5}\right), 149.88$ and $151.45(\mathrm{~m}$, $\mathrm{C}_{6} \mathrm{~A}$ and $\mathrm{B}$ ); mass spectrum $\mathrm{m} / \mathrm{z}$ (rel intensity) $378\left(\mathrm{M}^{+}, 70\right), 331$ $\left(\mathrm{M}^{+}\right.$- SMe, 100), $299\left(\mathrm{M}^{+}-\mathrm{SMe}-\mathrm{S}, 50\right), 220\left(\mathrm{M}^{+}-2 \mathrm{SMe}-2 \mathrm{~S}\right.$, 50). Anal. Calcd for $\mathrm{C}_{14} \mathrm{H}_{20} \mathrm{P}_{2} \mathrm{~S}_{4}: \mathrm{C}, 44.43 ; \mathrm{H}, 5.33 ; \mathrm{P}, 16.36 ; \mathrm{S}$, 33.88. Found: C, $44.67 ; \mathrm{H}, 5.30 ; \mathrm{P}, 15.98 ; \mathrm{S}, 34.03$.

$4,4^{\prime}, 5,5^{\prime}$-Tetramethyl-2,2'-bis(methylthio)-6,6'-bis (ethoxycarbonyl)-2,2'-diphospha-3,3'-bi[bicyclo[3.1.0]hex-3-enyl] $2,2^{\prime}$-Disulfide (15). To a solution of $2.0 \mathrm{~g}\left(5.3 \times 10^{-3} \mathrm{~mol}\right)$ of diphosphole disulfide 14 in xylene $(10 \mathrm{~mL})$ at $150^{\circ} \mathrm{C}$ was added $1.52 \mathrm{~g}\left(1.33 \times 10^{-2} \mathrm{~mol}\right)$ of ethyl diazoacetate over $10 \mathrm{~min}$. The mixture was stirred for $1 \mathrm{~h}$ at $150^{\circ} \mathrm{C}$ and then chromatographed first with dichloromethane and then with dichloromethane/ethyl acetate (80-20): yield $1.8 \mathrm{~g}(62 \%)$; mixture of two isomers; ${ }^{31} \mathrm{P}$ NMR (xylene) $\delta 81.6$ and 81.9. An analytical sample was recrystallized in dichloromethane, leading to one of the diastereoisomers: $\mathrm{mp} 224^{\circ} \mathrm{C}$; ${ }^{31} \mathrm{P}$ NMR $\left(\mathrm{CDCl}_{3}\right) \delta 80.5 ;{ }^{1} \mathrm{H}$ NMR $\left(\mathrm{CDCl}_{3}\right)$ $\delta 1.31\left(t,{ }^{3} J_{\mathrm{HH}}=7.1, \mathrm{CH}_{3}\right), 1.55\left(\mathrm{~s}, 3 \mathrm{H}, \mathrm{C}_{5}-\mathrm{CH}_{3}\right), 1.92$ (pseudo $\left.\mathrm{t}, 3 \mathrm{H}, \mathrm{C}_{4}-\mathrm{CH}_{3}\right), 2.30\left(\mathrm{~d},{ }^{3} \mathrm{~J}_{\mathrm{HP}}=14.4, \mathrm{SCH}_{3}\right), 2.05$ and $2.46(\mathrm{ABX}$; A part, dd, ${ }^{3} J_{\mathrm{HH}}=4.7,{ }^{3} J_{\mathrm{HP}}=13.2,1 \mathrm{H}, \mathrm{C}_{6}-\mathrm{H} ; \mathrm{B}$ part, dd, ${ }^{3} J_{\mathrm{HH}}$ $\left.=4.7,{ }^{2} J_{\mathrm{HP}}=12.5,1 \mathrm{H}, \mathrm{C}_{1}-\mathrm{H}\right), 4.20\left(\mathrm{ABX}_{3}, 2 \mathrm{H}, \mathrm{OCH}_{2}\right) ;{ }^{13} \mathrm{C} \mathrm{NMR}$ $\left(\mathrm{CDCl}_{3}\right) \delta 12.28\left(\mathrm{~s}, \mathrm{~S}-\mathrm{CH}_{3}\right), 14.25\left(\mathrm{~s}, \mathrm{CH}_{3}\right), 15.86\left(\mathrm{~s}, \mathrm{C}_{5}-\mathrm{SCH}_{3}\right), 16.40$ $\left(\mathrm{d},{ }^{3} \mathrm{~J}=13.4, \mathrm{C}_{4}-\mathrm{CH}_{3}\right), 31.79\left(\mathrm{~d},{ }_{\mathrm{J}}=77.3, \mathrm{C}_{1}\right), 37.55\left(\mathrm{~s}, \mathrm{C}_{6}\right), 41.20$ $\left(\mathrm{d},{ }^{2} J=3.6, \mathrm{C}_{5}\right), 61.66\left(\mathrm{~s}, \mathrm{OCH}_{2}\right), 121.0\left(\mathrm{dd},{ }^{1} J=82.7,{ }^{2} J=13.7\right.$, $\left.\mathrm{C}_{3}\right), 162.45\left(\mathrm{dd},{ }^{2} J=25.4,3 J=6.1, \mathrm{C}_{4}\right), 167.58\left(\mathrm{~s}, \mathrm{CO}_{2}\right)$; mass spectrum $m / z$ (rel intensity) $550\left(\mathrm{M}^{+}, 75\right), 503\left(\mathrm{M}^{+}-\mathrm{SMe}, 100\right)$. Anal. Calcd for $\mathrm{C}_{22} \mathrm{H}_{32} \mathrm{O}_{4} \mathrm{P}_{2} \mathrm{~S}_{4}: \mathrm{C}, 47.98 ; \mathrm{H}, 5.86 ; \mathrm{P}, 11.25 ; \mathrm{S}, 23.29$. Found: $\mathrm{C}, 47.73 ; \mathrm{H}, 5.95 ; \mathrm{P}, 10.96 ; \mathrm{S}, 23.31$.

$3,3^{\prime}, 4,4^{\prime}$-Tetramethyl-6, $6^{\prime}$-bis(ethoxycarbonyl)-2, $2^{\prime}$-biphosphinine (16). A mixture of $2.0 \mathrm{~g}\left(3.6 \times 10^{-3} \mathrm{~mol}\right)$ of the bis homophosphole sulfide 15 and $2.4 \mathrm{~g}\left(1.44 \mathrm{~g} \times 10^{-2} \mathrm{~mol}\right)$ of triethyl phosphite was heated for $20 \mathrm{~h}$ at $150^{\circ} \mathrm{C}$. After cooling, the residue was twice chromatographed with toluene, leading to $0.85 \mathrm{~g}$ of a mixture of two products: the biphosphinine $16, \delta{ }^{31} \mathrm{P}\left(\mathrm{CH}_{2} \mathrm{Cl}_{2}\right)$ 202.9 , and the homophosphole-phosphinine $17, \delta{ }^{31} \mathrm{P}\left(\mathrm{CH}_{2} \mathrm{Cl}_{2}\right)$ 207.7 (d) and 41.8 (d), ${ }^{3} J_{\mathrm{PP}}=7.3 \mathrm{~Hz}$. This mixture was once more chromatographed with toluene, giving first $0.3 \mathrm{~g}$ (yield $21.5 \%$ ) of the biphosphinine $16\left[{ }^{31} \mathrm{P}\right.$ NMR $\left(\mathrm{CDCl}_{3}\right) \delta 202.6 ;{ }^{1} \mathrm{H}$ NMR $\left(\mathrm{CDCl}_{3}\right) \delta 1.40\left(\mathrm{t},{ }^{3} J_{\mathrm{HH}}=7.1,6 \mathrm{H}, \mathrm{CH}_{3}\right), 2.12\left(\mathrm{~s}, 6 \mathrm{H}, \mathrm{C}_{3}-\mathrm{CH}_{3}\right)$, $2.50\left(\mathrm{~s}, 6 \mathrm{H}, \mathrm{C}_{4}-\mathrm{CH}_{3}\right), 4.41\left(\mathrm{q},{ }^{3} \mathrm{~J}_{\mathrm{HH}}=7.1,4 \mathrm{H}, \mathrm{OCH}_{2}\right), 8.45(\mathrm{~s}$, $\left.2 \mathrm{H}, \mathrm{C}_{5}-\mathrm{H}\right) ;{ }^{13} \mathrm{C} \mathrm{NMR}\left(\mathrm{CDCl}_{3}\right) \delta 14.35\left(\mathrm{~s}, \mathrm{CH}_{3}\right), 16.61\left(\mathrm{~s}, \mathrm{C}_{3}-\mathrm{CH}_{3}\right)$, $23.35\left(\mathrm{~s}, \mathrm{C}_{4}-\mathrm{CH}_{3}\right), 61.47\left(\mathrm{~s}, \mathrm{OCH}_{2}\right), 138.54$ (pseudo $\mathrm{t}, \mathrm{C}_{5}$ ), 140.42 (pseudo t, $\mathrm{C}_{3}$ ), $144.97\left(\mathrm{~s}, \mathrm{C}_{4}\right), 153.90\left(\mathrm{AXX}^{\prime}, J=53.5, \mathrm{C}_{6}\right), 168.10$ (pseudo t, $\mathrm{C}_{2}$ ), $172.10\left(\mathrm{AXX}^{\prime},{ }^{2} \mathrm{~J}=21.4, \mathrm{CO}_{2}\right.$ ); mass spectrum $\mathrm{m} / \mathrm{z}$ (rel intensity) $390\left(\mathrm{M}^{+}, 100\right)$. Anal. Calcd for $\mathrm{C}_{20} \mathrm{H}_{24} \mathrm{O}_{4} \mathrm{P}_{2}$ : $\mathrm{C}$, $61.54 ; \mathrm{H}, 6.20 ; \mathrm{P}, 15.87$. Found: $\mathrm{C}, 61.80 ; \mathrm{H}, 6.39 ; \mathrm{P}, 15.55$.] and then $0.2 \mathrm{~g}$ of a mixture of about $30 \%$ of the biphosphinine 16 and $70 \%$ of the compound $17\left[{ }^{1} \mathrm{H}\right.$ NMR $\left(\mathrm{CDCl}_{3}\right) \delta 8.35\left(\mathrm{~d},{ }^{3} \mathrm{~J}=4.3\right.$, $\left.0.55 \mathrm{H}, 17 \mathrm{C}_{5}-\mathrm{H}\right), 8.44\left(\mathrm{~s}, 0.45 \mathrm{H}, 16 \mathrm{C}_{5}-\mathrm{H}\right)$; mass spectrum $\mathrm{m} / \mathrm{z}$ (rel intensity) $438\left(17 \mathrm{M}^{+}, 70\right), 390\left(16 \mathrm{M}^{+}, 100\right), 365\left(17 \mathrm{M}^{+}\right.$$\left.\left.\mathrm{CO}_{2} \mathrm{Et}, 90\right), 317\left(16 \mathrm{M}^{+}-\mathrm{CO}_{2} \mathrm{Et}, 30\right)\right]$.

Supplementary Material Available: Structural report for 7, including a description of data collection, atomic coordinates, anisotropic thermal parameters, bond lengths, and bond angles (7 pages). Ordering information is given on any current masthead page.

\title{
Nickel-Catalyzed Olefination of Cyclic Benzylic Dithioacetals by Grignard Reagents. Scope and Mechanism ${ }^{1}$
}

\author{
Zhi-Jie Ni, ${ }^{2 a}$ Nai-Wen Mei, ${ }^{2 b}$ Xian Shi, ${ }^{2 a}$ Yih-Ling Tzeng, ${ }^{2 b}$ Maw Cherng Wang, ${ }^{2 b}$ and \\ Tien-Yau Luh*,2a-c \\ Department of Chemistry, National Taiwan University, Taipei, Taiwan 10764, Republic of China, and
} Department of Chemistry, The Chinese University of Hong Kong, Shatin, N.T., Hong Kong

Received August 23, 1990 (Revised Manuscript Received February 20, 1991)

\begin{abstract}
The details of the first nickel-catalyzed olefination of cyclic dithioacetals to form substituted styrenes and aryl-substituted 1,4-pentadienes are described. The reaction represents a new synthetic use of the dithioacetal functionality. Only nickel complexes catalyzed these cross-coupling reactions; palladium complexes displayed no catalytic activity under the reaction conditions employed. Selective coupling occurred. A mechanism for the reaction is proposed. The experimental evidence indicates that, in these nickel-catalyzed couplings, cyclic dithioacetals are more reactive than their acyclic analogues. This increased reactivity appears to be the result of maintaining the two sulfur atoms in close proximity to each other by the use of a short chain of methylene groups.
\end{abstract}

The dithioacetal functionality was first described in $1885^{3}$ Since that time it has come to be considered a latent carbonyl or methylene group, ${ }^{4,5}$ However, reports of the transformation of the dithioacetal functionality to

(1) Transition Metal Promoted Reactions. 33.

(2) The Chinese University of Hong Kong. (b) National Taiwan University. (c) To whom correspondence should be addressed at National Taiwan University.

(3) Baumann, E. Ber. Dtsch. Chem. Ges. 1885, 18, 883

(4) (a) Loewenthal, H. J. E. In Protecting Groups in Organic Chemistry; McOmie, J. F. W., Ed.; Plenum Press: New York, 1973; Chapter 9. (b) Greene, T. W. Protective Groups in Organic Synthesis; Wiley: New York, 1981; $p 129$.

(5) (a) Grobbel, B. T.; Seebach, D. Synthesis 1977, 357. (b) Page, P. C. B.; van Niel, M. B.; Prodger, J. C. Tetrahedron 1989, 45, 7603. other functional groups have been few. ${ }^{6-8}$ In general, the dithioacetal functionality is relatively stable toward nu-

(6) (a) Wilson, S. R.; Georgiadis, G. M.; Khatri, K. N.; Bartmess, J. E. J. Am. Chem. Soc. 1980, 102, 3577. (b) Ikehira, H.; Tanimoto, S.; Oida, T. Okano, M. Synthesis 1982, 1087. (c) Bartals, B.; Hunter, R.: Simon. C. D.; Tomlinson, G. D. Tetrahedron Lett. 1987, 28, 2985. (d) Denis, T. N.; Krief, A. Tetrahedron Lett. 1982, 23, 3407. (e) Itter, N. S.; Steckhan, E. Tetrahedron 1987, 43, 2475. (f) For review on the use of ketene dithioacetals in organic synthesis, see: Kolb, M. Synthesis 1990, 171.

(7) (a) Pandy-Szekeres, D.; Deleris, G.; Picard, J.-P.; Pillot, J. P.; Calas, R. Tetrahedron Lett. 1980, 21, 4267. (b) Trost, B. M.; Murayama, E. J. Am. Chem. Soc. 1981, 103, 6529. (c) Ohshima, M.; Muraikami, M.; Mukaiyama, T. Chem. Lett. 1985, 1871. (d) Saigo, K.; Hashimoto, Y.; Kihara, N.; Hara, K.-i.: Hasegawa, M. Chem. Lett. 1990, 1097. (e) Tsai, Y.-M.; Chang, F.-C.; Huang, J.; Shiu, C.-L. Tetrahedron Lett. 1989, 30, 2121. (f) Tsai, Y.-M.; Ke, B.-M.; Lin, C.-H. Tetrahedron Lett. 1990, 31, 6047. 
Table 1. Effect of Catalyet on the Coupling of 1 with MeMgI at Room Temperature

\begin{tabular}{ccccc}
\hline entry & catalyst & mol \% & reactn time, $\mathrm{h}$ & yield (\%) \\
\hline 1 & $\mathrm{NiCl}_{2}\left(\mathrm{PPh}_{3}\right)_{2}$ & 6 & 18 & 70 \\
2 & $\mathrm{NiBr}_{2} \cdot \mathrm{DME}^{6}$ & 6 & 16 & 68 \\
3 & $\mathrm{NiCl}_{2}(\mathrm{dppe})$ & 4 & 60 & 37 \\
4 & $\mathrm{NiCl}_{2}(\mathrm{dppp})$ & 5 & 60 & 51 \\
5 & $\left.\mathrm{Pd}^{\mathrm{P}} \mathrm{PPh}_{3}\right)_{4}$ & 4 & 16 & $0^{b}$ \\
6 & $\mathrm{PdCl}_{2}\left(\mathrm{PPh}_{3}\right)_{2}$ & 8 & 16 & $0^{b}$
\end{tabular}

${ }^{a} \mathrm{Ph}_{\mathrm{g}} \mathrm{P}$ (12 mol \%) was also present. ' $T$ The reaction was carried out under reflux.

cleophiles. In a few cases, nucleophilic attack has led to carbon-carbon bond formation. ${ }^{7}$ More recently, carbonyls of group 6 metals have been shown to convert dithioacetals to yield dimeric olefins. ${ }^{8}$ Sulfur-containing organometallic complexes have been obtained from the reaction of dithioacetals and certain metal carbonyls. ${ }^{9}$

Several nickel complexes are highly thiophilic. The conversion of a C-S bond to a $\mathrm{C}-\mathrm{H}$ bond ${ }^{10,11}$ or to a $\mathrm{C}-\mathrm{C}$ bond ${ }^{10,12}$ induced by homogeneous nickel catalysts is well-documented. Examples of the latter include the coupling of allylic, aryl, and vinylic mercaptans, thioethers, and sulfones. However, benzyl methyl sulfide gave diphenylmethane in less than $9 \%$ yield upon treatment with $\mathrm{PhMgBr}$ in the presence of various catalysts, ${ }^{13}$ and simple aliphatic thioethers were unreactive under various conditions. ${ }^{12 b}$

Benzylic dithiolanes and dithianes possess two carbonsulfur bonds. The ease with which such carbon-sulfur bonds are cleaved appears to be greater than that of the carbon-sulfur bond of simple benzylic thioethers. Furthermore, the close proximity of the two sulfur atoms to each other apparently plays a part in the facile cleavage of both carbon-sulfur bonds during these nickel-catalyzed reactions. One carbon-sulfur bond is broken and is replaced by a carbon-carbon bond, whereas the other is broken followed by a $\beta$-elimination which produces an olefin. This paper describes the scope and mechanism of the nickel-catalyzed olefination of cyclic benzylic dithioacetals. ${ }^{14}$

(8) (a) Wong, C. S.; Leung, W. S.; Leung, L. L.; Luh, T.-Y. J. Organomet. Chem. 1986, 307, C49. (b) Yeung, L. L.; Yip, Y. C.; Luh, T.-Y J. Chem. Soc., Chem. Commun. 1987, 981. (c) Ng, D. K. P.; Luh, T.-Y. Tetrahedron Lett. 1988, 29, 5131. (d) Wang, X.-j.; Luh, T.-Y.J. Org. Chem 1989, 54, 263. (e) Yeung, L. L. Yip Y C. Luh, T.Y.J. Org. Chem. 1990, 55, 1874. (f) Yip, Y. C.; Wang, X.-j.; Ng, D. K. P.; Mak, T C. W.; Chiang, P.; Luh, T. Y. J. Org. Chem. 1990, 55, 1881. (g) Kuo C.-H.; Luh, T.Y. J. Chem. Soc., Chem. Commun. 1990, 1187. (h) Fang, F. G. Danishefsky, S. J. Tetrahedron Lett. 1989, 30, 2747. (i) Fang, F. G.; Majer, M. E.; Danieshefsky, S. J.; Schulte, G. J. Org. Chem. 1990, 55, 831

(9) (a) Raubenheimer, H. G.; Linford, L.; Lombard, A. y. A. Organometallics 1989, 8, 2062. (b) Abel, E. W.; Mackenzie, T. E.; Orrell, K. G. Sik, V. Polyhedron 1987, 6, 1785. (c) Shaver, A.; Fitzpatrick, P. J. Steliou, K.; Butler, I. S. J. Am. Chem. Soc. 1979, 101, 1313.

(10) For a review, see: Luh, T.-Y.; Ni, Z.-J. Synthesis 1990, 89

(11) (a) Eisch, J. J.; Hallenbeck, L. E.; Han, K. I. J. Org. Chem. 1983, 48, 2963. (b) Eisch. J. J.; Hallenbeck. L. E. Han, K. I. J Am. Chem Soc 1986, 108, 7763. (c) Chan, M.-C.; Cheng, K.-M.; Li, M. K.; Luh, T.-Y.J. Chem. Soc., Chem. Commun. 1985, 1610. (d) Chan, M.-C.; Cheng, K.-M. Ho, K. M.; Ng, C. T.; Yam, T. M.; Wang, B. S. L.; Luh, T.-Y. J. Org Chem. 1988, 53, 4466. (e) Ho, K. M.; Lam, C. H.; Luh, T.-Y. J. Org. Chem. 1989, 54, 4474 .

(12) (a) Okamura, H.; Miura, M.; Takei, H. Tetrahedron Lett. 1979, 43. (b) Wenkert, E.; Ferreira, T. W.; Michelotti, E. L. J. Chem. Soc. Chem. Commun. 1979, 637.

(13) Okamura, H.; Takei, H. Tetrahedron Lett. 1979, 20, 3425.

(14) (a) Ni, Z.-J.; Luh, T.-Y. J. Chem. Soc., Chem. Commun. 1987, 1515. (b) Ni, Z.-J.; Luh, T.-Y. J. Org. Chem. 1988, 53, 2129. (c) Ng, D. K. P.; Luh, T.YY.J. Am. Chem. Soc. 1989, 111, 9119. (d) Ni, Z.-J.; Yang P.-F.; Ng. D. K. P.; Tzeng, Y.-L.; Luh, T.-Y. J. Am. Chem. Soc. 1990, 112 , 9356.

\section{Results and Discussion}

The Effect of the Catalyst. The reaction of 2,2-diphenyl-1,3-dithiolane (1) with MeMgI was examined in detail. For example, treatment of 1 at room temperature with $\mathrm{MeMgI}$ in the presence of catalytic amounts of $\mathrm{NiBr}_{2} \cdot \mathrm{DME}$ and $\mathrm{Ph}_{3} \mathrm{P}$ gave 1,1-diphenylethene (2a) in $68 \%$ yield (Table I, entry 2 ). The use of 3 equiv of the

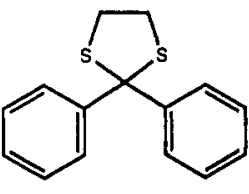

1

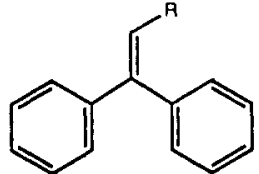

2 a $R=11$

b R $\square \mathrm{Me}$

c $\mathbf{R}=\mathbf{P r}$
Grignard reagent was necessary to force the reaction to completion. Table I shows the effect of the catalyst on the product yield. The most effective catalyst was $\mathrm{NiCl}_{2}$ $\left(\mathrm{PPh}_{3}\right)_{2}$. This compound is less hygroscopic and easier to handle than $\mathrm{NiBr}_{2}$-DME. Nickel catalysts that bear bidentate phosphine ligands like $\mathrm{Ph}_{2} \mathrm{P}\left(\mathrm{CH}_{2}\right)_{2} \mathrm{PPh}_{2}$ (dppe) or $\mathrm{Ph}_{2} \mathrm{P}\left(\mathrm{CH}_{2}\right)_{3} \mathrm{PPh}_{2}$ (dppp) were also effective, but more drastic conditions were required for reaction to occur (entries 3 and 4). ${ }^{15}$ However, $\mathrm{Pd}\left(\mathrm{PPh}_{3}\right)_{4}$ and $\mathrm{PdCl}_{2}\left(\mathrm{PPh}_{3}\right)_{2}$ were ineffective catalysts (entries 5 and 6 ). No reaction of 1 and Grignard reagents occurred in the absence of a nickel catalyst. It should be noted that benzylic acetals and Grignard reagents do react in the absence of a transition-metal catalyst to give alkylated ethers. ${ }^{16}$

The Effect of the Nucleophile. Grignard reagents of various types reacted with cyclic dithioacetals under the reaction conditions employed. For example, when 1 was treated with $\mathrm{EtMgBr}$ or $\mathrm{BuMgBr}$, the corresponding coupling product, $2 \mathbf{b}$ or $2 \mathrm{c}$, was obtained in good yield. Alkyllithiums also react with dithiolanes to give mercaptans. ${ }^{6 a}$ Under our reaction conditions, this reaction com. peted with cross coupling. Thus, the reaction of $3 \mathbf{a}$ with methyllithium gave a mixture of mercaptan 4 and olefin 5 in yields of $43 \%$ and $31 \%$, respectively. However, when

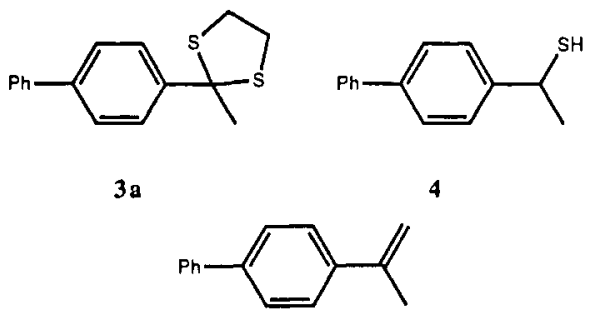

5

six-membered cyclic dithianes were employed, coupling with organolithium reagents went smoothly. Organozinc and organotin reagents failed to react with 1.

Olefination of Cyclic Benzylic Dithioacetals. The presence of two aryl groups in the dithioacetal was not necessary for coupling to occur. Dithioacetals 6 of benzylic aldehydes afforded the corresponding styrenes 7 in good yields. The results of the nickel-catalyzed olefination of various dithioacetals are summarized in Table II. Thus,

(15) When $\mathrm{NiCl}_{2}$ (dppe) was used as the catalyst and the reaction was carried out at elevated temperatures (e.g., in refluxing benzene), a side reaction yielded significant amounts of geminal-dimethylated products. See: Yang, P.-F.; Ni, Z.-J.; Luh, T.-Y.J. Org. Chem. 1989, 54, 2261. Mei, N.-W.; Luh, T.-Y., unpublished results.

(16) Wenkert, E.; Ferreira, T. W. Organometallics 1982, 1, 1670. 


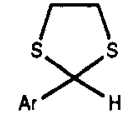

6

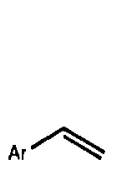

7

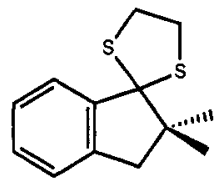

8

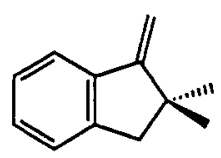

9 1,4-divinylbenzene (7e) was synthesized by this procedure (entry 11). An aryl ether linkage (entry 10) ${ }^{17}$ remained intact under the reaction conditions. Although the C-S bond of thiophene can be cleaved under similar reaction conditions, ${ }^{18,19}$ it apparently is cleaved less readily than the $\mathrm{C}-\mathrm{S}$ bond of cyclic dithioacetals. Thus, $7 \mathrm{f}$ was isolated from the reaction of $6 f$ in moderate yield (entry 12). The scope of the reaction could be extended to include sterically hindered dithioacetals. Thus, 8 gave the olefin 9 , which possesses an exocyclic carbon-carbon double bond, in $78 \%$ yield.

Aryl halides are reactive under the conditions employed. ${ }^{14,20}$ Both nickel and palladium compounds catalyze the coupling of aryl halides with Grignard reagents. ${ }^{20}$ As mentioned earlier, neither $\mathrm{Pd}(0)$ nor $\mathrm{Pd}(\mathrm{II})$ complexes catalyze the reaction of dithioacetals with Grignard reagents. Consequently, a chemoselective reaction could be achieved when both halide and dithioacetal functionalities were present. Equation 1 illustrates the application of this strategy to the synthesis of substituted styrenes. ${ }^{21}$<smiles>[X]c1ccccc1C1SCCS1</smiles>

$10 \mathrm{a} X=2-\mathrm{Br}, \mathrm{n}=1$ $10 \mathrm{~b} X=3-\mathrm{Br}, \mathrm{n}=2$

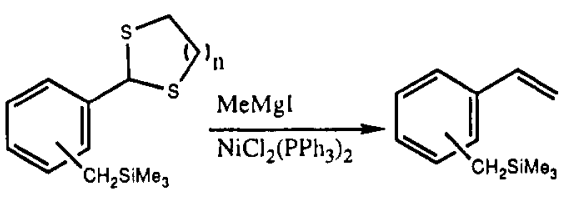

$11 \mathrm{a}(\mathrm{n}=1) 98 \%$

12a $86 \%$

$11 \mathrm{~b}(\mathrm{n}=2) 99 \%$

12b $84 \%$

The dithioketals of cyclic ketones reacted to give olefins possessing endocyclic carbon-carbon double bonds as the sole products. For example, 3-methyl-1 $H$-indene (14a) and 4-methyl-1,2-dihydronaphthalene (14b) were obtained, in $69 \%$ and $60 \%$ yield, respectively, from $13 \mathrm{a}$ and $13 \mathrm{~b}$.

Cyclic dithioketals of methyl aryl ketones also reacted smoothly with MeMgI under the reaction conditions to give $\alpha$-methylstyrenes. For example, $3 \mathrm{a}$ and $\mathrm{MeMgI}$ reacted at room temperature to afford 5 in $95 \%$ yield.

(17) The $\mathrm{C}-\mathrm{O}$ bond of aryl methyl ethers can be cleaved under similar conditions. See: Wenkert, E.; Michelotti, E. L.; Swindell, C. S. J. Am. Chem. Soc. 1979, 101, 2246.

(18) Wenkert, E.; Leftin, M. H.; Michelotti, E. L. J. Chem. Soc., Chem. Commun. 1984, 617 .

(19) Tiecco, M.; Tingoli, M.; Wenkert, E. J. Org. Chem. 1985, 50, 3828

(20) Kumada, M. Pure Appl. Chem. 1980, 52, 669.

(21) The related sequential cross coupling has been used extensively for the synthesis of olefins. See: Naso, F. Pure Appl. Chem. 1988, 60, 79.

(22) (a) Wenkert, E.; Shepard, M. E.; McPhail, A. T. J. Chem. Soc., Chem. Commun. 1986, 1390. (b) Osakada, K.; Maeda, M.; Nakamura, Y.; Yamamoto, T.; Yamamoto, A. J. Chem. Soc., Chem. Commun. 1986, 442.

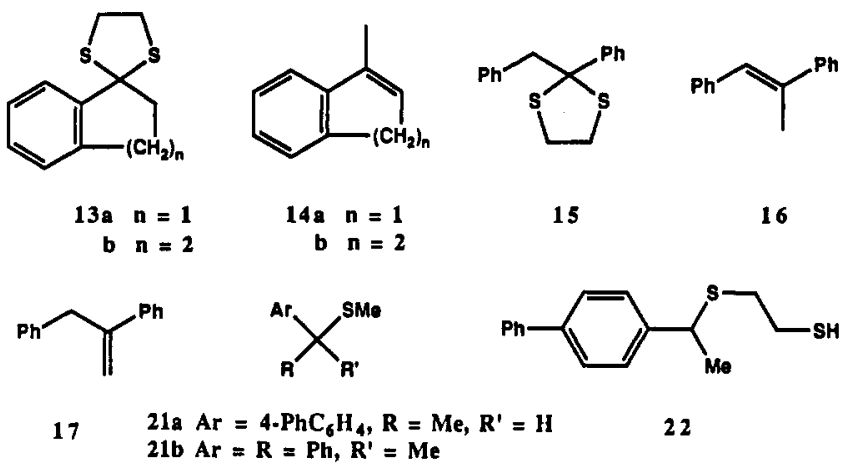

When dithioketal 15 was allowed to react with $\mathrm{MeMgI}$, a 2:1 mixture of the isomers 16 and 17 was obtained in $94 \%$ yield. This result provided further evidence in support of the belief that the carbon-carbon bond was formed prior to the $\beta$-elimination, and the $\beta$-elimination was not selective. Thus, a mixture of isomeric olefins was produced.

The Mechanism of the Reaction. A plausible catalytic pathway for the olefination of dithioacetals, which is based on the general catalytic cycle ${ }^{12,20}$ proposed for the coupling of aryl halides or sulfides with Grignard reagents, is outlined in Scheme I. The nickel(II) catalyst is first reduced to nickel $(0)$ by the Grignard reagent. Evidence for this step was provided by the observation that, when $\mathrm{MeMgI}$ and $\mathrm{Me}_{3} \mathrm{SiCH}_{2} \mathrm{MgCl}$ were treated with a stoichiometric amount of $\mathrm{NiCl}_{2}\left(\mathrm{PPh}_{3}\right)_{2}$, ethane and $\mathrm{Me}_{3} \mathrm{SiCH}_{2} \mathrm{CH}_{2} \mathrm{SiMe}_{3}$ were detected by GC-MS. Then the two carbon-sulfur bonds of the dithioacetal are cleaved in succession. Thus, the oxidative addition of $\mathrm{Ni}(0)$ to the first carbon-sulfur bond produces the sulfur-coordinated intermediate 18. In the next step, the alkyl group of the Grignard reagent may associate with nickel, followed by reductive elimination, to give the corresponding alkylated intermediate 19.

That intermediate 19 is indeed formed was not confirmed. Attempts to detect 19 in the reaction mixture containing 1, MeMgI, and various amounts of $\mathrm{NiCl}_{2}\left(\mathrm{PPh}_{3}\right)_{2}$ were unsuccessful. The reaction of 1 with 1.5 equiv of $\mathrm{MeMgI}$ under the usual conditions gave only $2 \mathrm{a}$ and recovered starting material. These results implied that the rate of cleavage of the second carbon-sulfur bond was faster than that of the first carbon-sulfur bond. As mentioned earlier, benzylic thioether gave poor yields of coupling products. ${ }^{13}$ It was also found that all of the benzylic thioether 21a was recovered after attempted reaction with Grignard reagents at room temperature. Even the more reactive $2 b$ under reflux gave olefin $2 a$ in only $41 \%$ yield. No coupling product was obtained. It should be noted that the sulfide anion moiety in 19 is capable of coordination with the nickel species. Such coordination would facilitate the subsequent oxidative addition step, which leads to the cleavage of the second carbon-sulfur bond.

To test this hypothesis, sulfide 22, which was synthesized by the partial reduction of dithiolane $3 a$ with tri-n-butyltin hydride, ${ }^{23}$ was allowed to react with $\mathrm{MeMgI}$ in the presence of $\mathrm{NiCl}_{2}\left(\mathrm{PPh}_{3}\right)_{2}$ at room temperature. The reaction gave olefin $7 \mathrm{~g}$ in $61 \%$ yield. This result suggested that the coordination of the sulfide anion with the nickel atom did indeed assist in the cleavage of the carbon-sulfur bond of 19. Thus, in the nickel-catalyzed coupling reactions of cyclic dithioacetals and Grignard reagents, the tandem cleavage of the two carbon-sulfur bonds occurs rapidly. The nickel-catalyzed intermolecular cleavage of the first

(23) Gutierrez, C. G.; Stringham, R. A.; Nitasaka, T.; Glasecock, K. G. J. Org. Chem. 1980, 45, 3393. 
Table II. Preparation of Styrenes by the Reaction of Cyclic Dithioacetals 6 with MeMgI in the Presence of $\mathrm{NiCl}_{\mathbf{8}}\left(\mathrm{PPh}_{3}\right)_{2}$
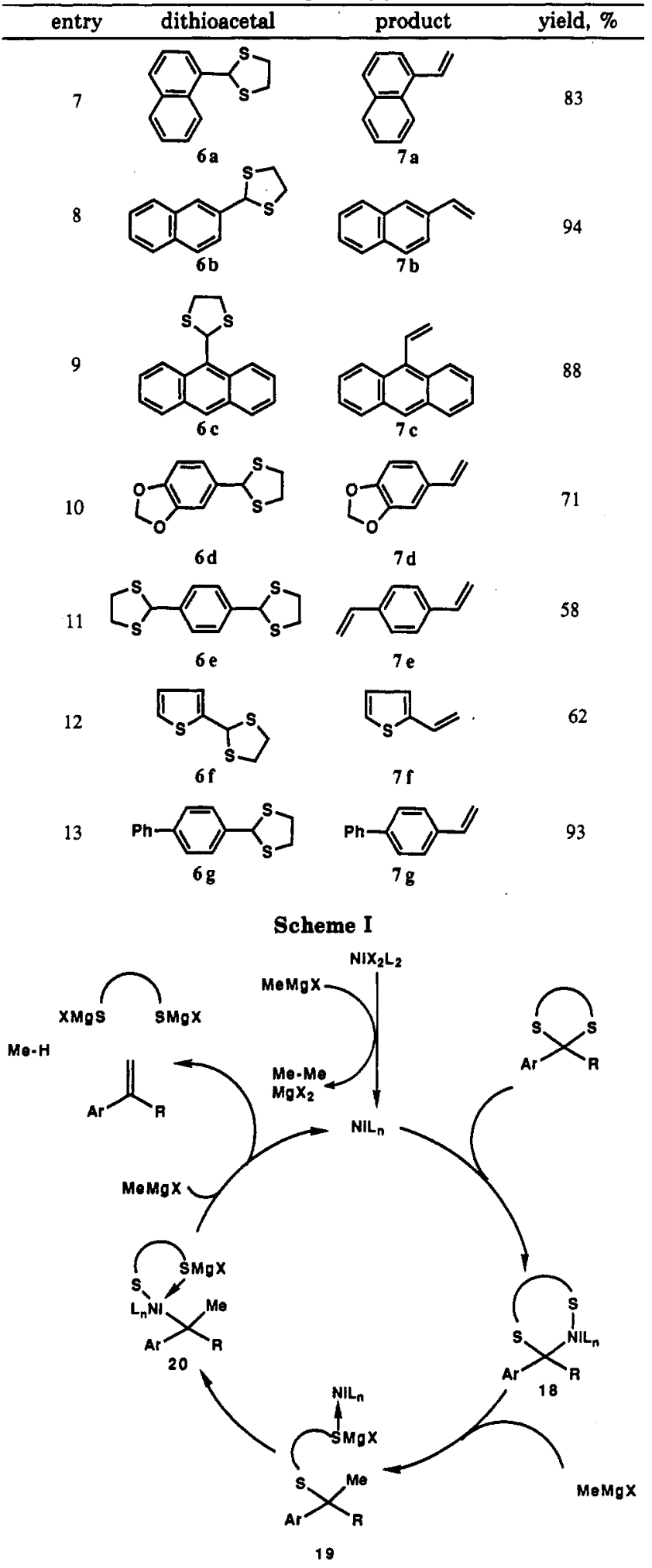

carbon-sulfur bond yields a product that promotes a subsequent intramolecular oxidative addition of the nickel species to the second carbon-sulfur bond. Thus, it was not surprising that the acyclic dithioacetal 23 proved to be much less reactive than the acyclic dithioacetals $6 \mathrm{~g}^{24}$

(24) Stilbene and sulfur-containing dimers were occasionally obtained as side products when more vigorous conditions (e.g., refluxing benzene) were employed. See: Ni, Z.-J. Ph.D. Dissertation, The Chinese University of Hong Kong, 1989.

Cleavage of the second carbon-sulfur bond would give the sterically crowded alkylnickel intermediate 20. Then $\beta$-elimination of a sulfur-containing nickel complex would give an olefin. Alternatively, the Grignard reagent may attack 20. Subsequent $\beta$-elimination would then yield an olefin and intermediate 24. If the latter reaction took place, the hydrocarbon derived from the Grignard reagent would be expected to be formed by subsequent reductive elimination from 24 . The active nickel $(0)$ catalyst would thus be regenerated.<smiles>CCC(CC)c1ccc(-c2ccccc2)cc1</smiles>

23

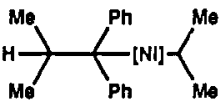

27

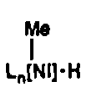

24

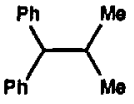

25<smiles></smiles>

26

Several pieces of evidence support the conjecture that the Grignard reagent attacks 20 before $\beta$-elimination takes place. When $\mathrm{Me}_{3} \mathrm{SiCH}_{2} \mathrm{MgCl}$ was allowed to react with 1 under the usual conditions, $\mathrm{Me}_{4} \mathrm{Si}$ was detected by GCMS. Furthermore, reductive elimination could competitively give a dialkylated side product, for geminal dialkylation was observed in $\mathrm{NiCl}_{2}$ (dppe)-catalyzed reactions. ${ }^{15}$ However, the data in Tables I and II show the absence of dimethylated products from the reactions of cyclic benzylic dithioacetals in the presence of $\mathrm{NiCl}_{2}\left(\mathrm{PPh}_{3}\right)_{2}$ catalyst. These results indicate that the $\beta$-elimination occurred rapidly.

The results of the reaction of dithioacetal 1 with a secondary Grignard reagent are worth noting. When 1 was treated at room temperature with $i$-PrMgBr, a $6.7: 1 \mathrm{mix}$ ture of 1,1-diphenyl-2-methylpropane (25) and 1,1-diphenyl-2-methylpropene (26) was produced. This result was somewhat different from those of the reactions of 1 with straight-chain Grignard reagents, which yielded no reduction products. The formation of $\mathbf{2 6}$ is consistent with the mechanism shown in Scheme I. Apparently, intermediate 27 can undergo $\beta$-hydride elimination involving either the secondary alkyl group or the 1,1-diphenyl-2methylpropyl group to give nickel hydride 28 or 29 , respectively. Reductive elimination of a nickel species from 28 would give 25 .

Similarly, when the highly sterically hindered dithioketal 30a was treated with EtMgBr under the usual conditions, the reduction product $30 \mathrm{~b}$ was obtained exclusively, in $56 \%$ yield. Again, steric congestion in the reaction intermediate would favor $\beta$-elimination involving the ethyl group. Reductive elimination would furnish the reduction product. These results clearly indicated that some sort of interaction between the Grignard reagent and 20 prior to $\beta$-elimination was essential.<smiles>[1H]C([2H])([18OH])c1ccc2ccccc2c1</smiles>

30a $\mathrm{R}-\mathrm{R}=-\mathrm{S}\left(\mathrm{CH}_{2}\right)_{3} \mathrm{~S}$. 30b $R=H$<smiles>c1ccccc1</smiles>

31

The fate of the sulfur moiety in these coupling reactions has been determined. Thus, to a reaction mixture of 1 and $\mathrm{MeMgI}$ under the usual conditions were added in suc- 
Table III. Preparation of 2-Aryl-1,4-pentadienes by the Reaction of Cyclic Dithioketals 3 with Allylmagnesium Halides in the Presence of the Nickel Catalyst

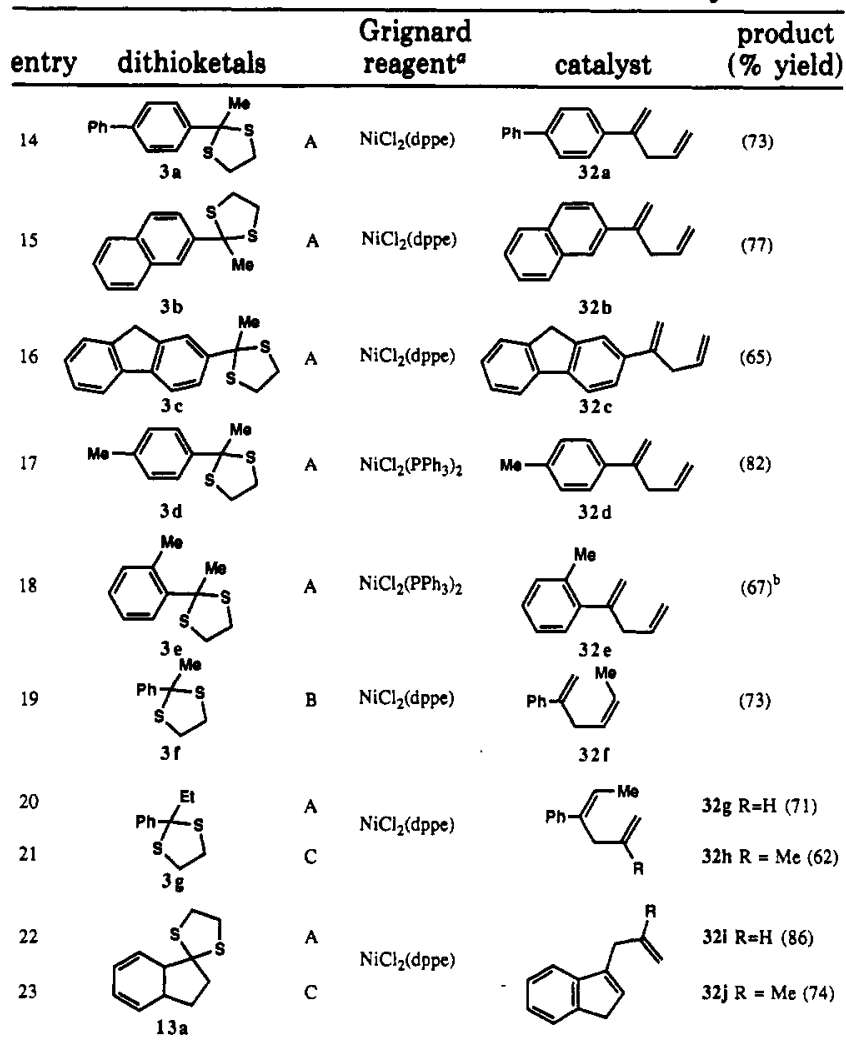

a A, $\mathrm{CH}_{2}=\mathrm{CHCH}_{2} \mathrm{MgBr} ; \mathrm{B}, \mathrm{MeCH}=\mathrm{CHCH}_{2} \mathrm{MgCl} ; \mathrm{C}, \mathrm{CH}_{2}=\mathrm{C}-$ $(\mathrm{Me}) \mathrm{CH}_{2} \mathrm{MgCl}$. ${ }^{b} 33$ was obtained in $15 \%$ yield.

cession aqueous $\mathrm{NaOH}$ and excess benzyl bromide. Workup gave the bisthioether 31 in $47 \%$ yield.

1,4-Pentadienes. It was recently shown that a cyclopropyl Grignard reagent could act as an allyl anion synthon in nickel-catalyzed cross couplings with dithioacetals (eq 2). ${ }^{14}$ A comparison of the behavior of the allyl Grignard<smiles>[2H]/C([3H])=C\C=C</smiles>

reagent and that of its cyclopropyl analogue proved informative. Hence, when a benzene solution of each of the dithioacetals 3 was refluxed with an allylmagnesium bromide in the presence of $5 \mathrm{~mol} \%$ of either $\mathrm{NiCl}_{2}$ (dppe) or $\mathrm{NiCl}_{2}\left(\mathrm{PPh}_{3}\right)_{2}$, the corresponding 1,4-pentadiene (32) was produced (Table III).

Similar results were obtained from the reactions of methallyl and crotyl Grignard reagents (entries 19, 21, and 23). It was noteworthy that the reaction of crotylmagnesium chloride gave regio- and stereoselectively a single isomer (entry 19). The assignment of stereochem. istry to $32 f$ was based on an NOE experiment. The results were somewhat different from those of the coupling of vinyl triflates with crotyl cuprates, from which a mixture of regio- and stereoisomers was obtained. ${ }^{25}$ It is interesting to note that the reaction of the dithioketal of phenyl ethyl ketone stereospecifically yielded only one isomer (entries 20 and 21 ).

The regioselective formation of 1,4-dienes from dithioacetals is mechanistically interesting and synthetically useful. Presumably, the steric environment of the transition states (34 and 35 ) of the $\beta$-elimination step deter-

(25) Lipschutz, B. H.; Elworthy, T. R. J. Org. Chem. 1990, 55, 1695 and references therein. mines which diene is formed. 26 -elimination via 34 seems to have been favored. However, the degree of selectivity decreased with an increase in the degree of steric congestion in the dithioacetal. Hence, $3 \mathbf{e}$, in which an ortho methyl group was present on the aromatic ring, gave a significant amount of 33 (entry 18).<smiles>C=C/C=C(\C)c1ccccc1C</smiles>

33<smiles>C=CC=CC=CC=N</smiles>

34

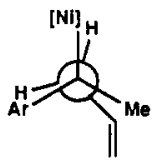

35

\section{Experimental Section}

General. Melting and boiling points are uncorrected. Schlenk techniques were used to manipulate air-sensitive compounds. ${ }^{27}$ All solvents were purified by standard methods. ${ }^{27 b}$ Tetrahydrofuran was distilled from sodium benzophenone ketyl. Benzene was distilled from sodium wire. $\mathrm{Et}_{2} \mathrm{O}$ was refluxed over and distilled from $\mathrm{LiAlH}_{4}$. $\mathrm{NiCl}_{2}\left(\mathrm{PPh}_{3}\right)_{2},{ }^{28} \mathrm{NiCl}_{2}$ (dppe), ${ }^{29}$ $\mathrm{NiCl}_{2}(\mathrm{dppp}),{ }^{29} \mathrm{PdCl}_{2}\left(\mathrm{PPh}_{3}\right)_{2},{ }^{30}$ and $\mathrm{Pd}\left(\mathrm{PPh}_{3}\right)_{4}{ }^{31}$ were prepared by literature methods.

Reaction of 2,2-Diphenyl-1,3-dithiolane (1) with MeMgI Catalyzed by $\mathrm{NiBr}_{2}$.DME and $\mathbf{P h}_{3} \mathbf{P}$. Dithioketal 1 (246 mg, $0.95 \mathrm{mmol}$ ), $\mathrm{NiBr}_{2} \cdot \mathrm{DME}$ (15 mg, $0.06 \mathrm{mmol}$ ), and $\mathrm{Ph}_{3} \mathrm{P}(30 \mathrm{mg}$, $0.11 \mathrm{mmol}$ ) were mixed under an atmosphere of dry $\mathrm{N}_{2}$. Benzene $(5 \mathrm{~mL})$ was introduced by syringe, and the mixture was immersed in an ice bath. To the stirred mixture was then added, in one portion, by syringe, MeMgI ( $3 \mathrm{~mL}, 1.0 \mathrm{M}$ in ether, $3 \mathrm{mmol}$ ). The mixture was stirred at room temperature for $16 \mathrm{~h}$. Then it was quenched with saturated aqueous $\mathrm{NH}_{4} \mathrm{Cl}(20 \mathrm{~mL})$. The two liquid layers were separated. The aqueous layer was then extracted with $\mathrm{Et}_{2} \mathrm{O}(2 \times 30 \mathrm{~mL})$. The combined organic layers were washed with $10 \%$ aqueous $\mathrm{NaOH}(2 \times 10 \mathrm{~mL})$ and water and were dried $\left(\mathrm{Na}_{2} \mathrm{SO}_{4}\right)$. The solvent was evaporated from the filtrate in vacuo. The residue was purified by column chromatography on silica gel (hexane) to give $2 \mathrm{a}^{32}$ as a colorless oil (126 mg, 68\%): IR (neat) $\nu 3050,3025,1653,1597,1440,1317,1275,1021,900,770,698 \mathrm{~cm}^{-1}$; ${ }^{1} \mathrm{H}$ NMR $(60 \mathrm{MHz}) \delta 5.35(\mathrm{~s}, 2 \mathrm{H}), 7.20(\mathrm{~s}, 10 \mathrm{H}) ; \mathrm{MS} \mathrm{m} / \mathrm{z}$ (relative intensity) $180\left(\mathrm{M}^{+}, 23.3\right), 77$ (base peak).

General Procedure for the Nickel-Catalyzed Coupling of Dithioacetal with "Simple" Alkyl Grignard Reagents. To an ice-cold stirred mixture of the dithioacetal, a catalytic amount (5-10 $\mathrm{mol} \%$ ) of $\mathrm{NiCl}_{2}\left(\mathrm{PPh}_{3}\right)_{2}$, and benzene was added the Grignard reagent (3-4 equiv, in $\mathrm{Et}_{2} \mathrm{O}$ ). The mixture was then stirred at room temperature until it was quenched with saturated aqueous $\mathrm{NH}_{4} \mathrm{Cl}$. The two liquid layers were separated. The aqueous portion was extracted with $\mathrm{Et}_{2} \mathrm{O}$. The combined organic layers were washed with $10 \%$ aqueous $\mathrm{NaOH}$ and water and were dried $\left(\mathrm{Na}_{2} \mathrm{SO}_{4}\right)$. After the solvent was evaporated from the filtrate in vacuo, the residue was purified by column chromatography on silica gel (hexane, unless otherwise specified) to give the olefin.

$\mathbf{N i C l}_{2}\left(\mathbf{P P h}_{3}\right)_{2}$-Catalyzed Reaction of 1 with $\mathbf{M e M g I . ~ I n ~ a ~}$ manner similar to that described in the general procedure, a mixture of $1(253 \mathrm{mg}, 0.98 \mathrm{mmol}), \mathrm{NiCl}_{2}\left(\mathrm{PPh}_{3}\right)_{2}(42 \mathrm{mg}, 0.06$ $\mathrm{mmol}$ ), and $\mathrm{MeMgI}$ ( $3 \mathrm{~mL}$ of a $1 \mathrm{M}$ solution in $\mathrm{Et}_{2} \mathrm{O}, 3 \mathrm{mmol}$ ) in benzene $(5 \mathrm{~mL})$ was stirred at room temperature for $18 \mathrm{~h}$ to give $2 \mathrm{a}(124 \mathrm{mg}, 70 \%)$.

$\mathrm{NiCl}_{2}$ (dppe)-Catalyzed Reaction of 1 with $\mathbf{M e M g I}$. In a manner similar to that described in the general procedure, $a$

(26) One referee suggested that coordination of the carbon-carbon double bond with nickel could lead to regioselective elimination to give the 1,4-diene.

(27) (a) Shriver, D. F. The Manipulation of Air-sensitive Compounds McGraw-Hill: New York, 1969. (b) Perrin, D. D.; Armarego, W. L. F.; Perrin, D. R. Purification of Laboratory Chemicals, 2nd ed.; Pergamon: New York, 1980.

(28) Cotton, F. A.; Fant, O. D.; Goodgame, D. M. L. J. Am. Chem. Soc. $1961,83,344$

(29) Van Hecke, G. R.; Horrocks, W. D., Jr. Inorg. Chem. 1966, 5, 1968.

(30) Tayim, H. A.; Bouldoukian, A.; Award, F. J. Inorg. Nucl. Chem $1970,32,3799$

(31) Coulson, D. R. Inorg. Synth. 1972, 13, 121.

(32) Allen, C. F. H.; Converse, S. Organic Syntheses; Collect. Vol. I, Wiley: New York, 1941; p 226. 
mixture of 1 (288 mg, $1.1 \mathrm{mmol})$ and $\mathrm{NiCl}_{2}(\mathrm{dppe})(25 \mathrm{mg}, 0.04$ $\mathrm{mmol}$ ) in benzene $(5 \mathrm{~mL})$ was allowed to react with $\mathrm{MeMgI}$ (3 $\mathrm{mL}$ of a $1 \mathrm{M}$ solution in $\mathrm{Et}_{2} \mathrm{O}, 3 \mathrm{mmol}$ ) at room temperature to afford $2 a(74 \mathrm{mg}, 37 \%)$.

$\mathrm{NiCl}_{2}$ (dppp)-Catalyzed Reaction of 1 with $\mathrm{MeMgI}$. In a manner similar to that described in the general procedure, a mixture of $1(250 \mathrm{mg}, 0.97 \mathrm{mmol})$ and $\mathrm{NiCl}_{2}(\mathrm{dppp})$ in benzene $(5 \mathrm{~mL}$ ) was allowed to react with $\mathrm{MeMgI}$ ( $3 \mathrm{~mL}$ of a $1 \mathrm{M}$ solution in $\left.\mathrm{Et}_{2} \mathrm{O}, 3 \mathrm{mmol}\right)$ at room temperature to afford $2 \mathrm{a}(89 \mathrm{mg}, 51 \%)$.

Attempted Palladium-Catalyzed Reaction of 1 with MeMgI. To a benzene solution $(2 \mathrm{~mL})$ of 1 (121 $\mathrm{mg}, 0.47 \mathrm{mmol})$ and $\mathrm{PdCl}_{2}\left(\mathrm{PPh}_{3}\right)_{2}(25 \mathrm{mg}, 0.036)$ was added MeMgI $(2 \mathrm{~mL}$ of a $1 \mathrm{M}$ solution in $\left.\mathrm{Et}_{2} \mathrm{O}, 2 \mathrm{mmol}\right)$. The yellow solution immediately became colorless. The reaction was monitored by TLC. After stirring for $16 \mathrm{~h}$, no sign of reaction was detected. The mixture was then heated under reflux for $20 \mathrm{~h}$. TLC analysis again showed that no reaction had occurred. After the usual workup, 1 was recovered ( $87 \mathrm{mg}, 72 \%$ ).

From a similar attempt, in which $\mathrm{Pd}\left(\mathrm{PPh}_{3}\right)_{4}$ was used as the catalyst, 1 was recovered in $85 \%$ yield.

1,1-Diphenylpropene (2b). In a manner similar to that described in the general procedure, a mixture of $1(243 \mathrm{mg}, 0.94$ $\mathrm{mmol}), \mathrm{NiCl}_{2}\left(\mathrm{PPh}_{3}\right)_{2}$ (33 mg, $\left.0.05 \mathrm{mmol}\right), \mathrm{EtMgBr}(3 \mathrm{~mL}$ of a 1 $\mathrm{M}$ solution in $\left.\mathrm{Et}_{2} \mathrm{O}, 3 \mathrm{mmol}\right)$, and benzene $(5 \mathrm{~mL})$ was stirred at room temperature for $15 \mathrm{~h}$ to afford $2 \mathrm{~b}^{33}$ (143 $\mathrm{mg}, 78 \%$ ): IR (neat) $3050,3020,2900,1650,1592,1490,1438,1270,1063,1023,918$, $838,750,695 \mathrm{~cm}^{-1}$; ${ }^{1} \mathrm{H}$ NMR $(60 \mathrm{MHz}) \delta 1.69(\mathrm{~d}, J=7 \mathrm{~Hz}, 3 \mathrm{H})$, $6.08(\mathrm{q}, J=7 \mathrm{~Hz}, 1 \mathrm{H}), 6.91-7.63(\mathrm{~m}, 10 \mathrm{H}) ; \mathrm{MS} m / z$ (relative intensity) $195\left(\mathrm{M}^{+}+1,16.5\right), 194\left(\mathrm{M}^{+}, 100.0\right), 193(58.8), 179(30.6)$, 117 (16.2), 91 (16.7).

1,1-Diphenylpentene (2c). In a manner similar to that described in the general procedure, a mixture of $1(252 \mathrm{mg}, 0.98$ mmol), $\mathrm{NiCl}_{2}\left(\mathrm{PPh}_{3}\right)_{2}$ (49 mg, $0.07 \mathrm{mmol}$ ), and benzene (5 mL) was allowed to react with $n-\mathrm{BuMgBr}(3 \mathrm{~mL}$ of a $1 \mathrm{M}$ solution in $\mathrm{Et}_{2} \mathrm{O}, 3 \mathrm{mmol}$ ) at room temperature for $16 \mathrm{~h}$ to give $2 \mathrm{c}^{34}$ (183 $\mathrm{mg}$, $84 \%$ ): IR (neat) $\nu 3051,2931,1650,1597,1495,1440,1310,1270$, $940,920,741,700 \mathrm{~cm}^{-1}$; ${ }^{1} \mathrm{H}$ NMR $(60 \mathrm{MHz}) \delta 0.88(\mathrm{t}, J=7 \mathrm{~Hz}$, $3 \mathrm{H}), 1.07-1.93(\mathrm{~m}, 2 \mathrm{H}), 2.07(\mathrm{dt}, J=7.5 \mathrm{~Hz}, J=5 \mathrm{~Hz}, 2 \mathrm{H})$, $6.05(\mathrm{t}, J=7.5 \mathrm{~Hz}, 1 \mathrm{H}), 6.95-7.65(\mathrm{~m}, 10 \mathrm{H}) ; \mathrm{MS} m / z$ (relative intensity) $223\left(\mathrm{M}^{+}+1,8.8\right), 222\left(\mathrm{M}^{+}, 46.7\right), 193(100.0), 178(23.5)$, 165 (15.8), 115 (67.9), 91 (32.7).

Reaction of 2-Methyl-2-(4-biphenylyl)-1,3-dithiolane (3a) with MeLi Catalyzed by $\mathrm{NiCl}_{2}\left(\mathbf{P P h}_{3}\right)_{2}$. To a stirred solution of $3 \mathrm{a}(95 \mathrm{mg}, 0.35 \mathrm{mmol}), \mathrm{NiCl}_{2}\left(\mathrm{PPh}_{3}\right)_{2}(22 \mathrm{mg}, 0.034 \mathrm{mmol})$, and benzene $(3 \mathrm{~mL})$ was added MeLi (10 mL of a $0.2 \mathrm{M}$ solution in $\mathrm{Et}_{2} \mathrm{O}, 2 \mathrm{mmol}$ ) under a $\mathrm{N}_{2}$ atmosphere. The mixture was refluxed for $16 \mathrm{~h}$ and was then cooled to room temperature, and water $(30$ $\mathrm{mL}$ ) was added. The aqueous layer was extracted with $\mathrm{E} \mathrm{t}_{2} \mathrm{O}$ (2 $\times 30 \mathrm{~mL}$ ). The combined organic layers were washed twice with water and dried $\left(\mathrm{Na}_{2} \mathrm{SO}_{4}\right)$. Evaporation of the solvent gave a solid. This was purified by column chromatography on silica gel (hexane) to afford 1-(4-biphenylyl)ethanethiol (4) $(32 \mathrm{mg}, 43 \%)$ and 2(4-biphenylyl)propene (5) (21 mg, 31\%). 4: IR (neat) $\nu 3051,3009$, $2911,1595,1481,1445,1422,1380,1270,1155,1102,901,842,723$ $\mathrm{cm}^{-1}$; ${ }^{1} \mathrm{H}$ NMR $(60 \mathrm{MHz}) \delta 1.68(\mathrm{~d}, J=7 \mathrm{~Hz}, 3 \mathrm{H}), 2.02(\mathrm{~d}, J=$ $5 \mathrm{~Hz}, 1 \mathrm{H}), 4.0-4.51(\mathrm{~m}, 1 \mathrm{H}), 7.03-7.90(\mathrm{~m}, 9 \mathrm{H})$; exact mass calcd for $\mathrm{C}_{14} \mathrm{H}_{14} \mathrm{~S} 214.0816$, found 214.0813 . 5: $\mathrm{mp} 117-118{ }^{\circ} \mathrm{C}$ (lit. ${ }^{36}$ mp 119-119.5 $\left.{ }^{\circ} \mathrm{C}\right)$; IR (KBr) $\nu 3040,2980,2930,1688,1627,1585$, $1489,1411,1005,837,841,770,737,690 \mathrm{~cm}^{-1}$; ${ }^{1} \mathrm{H}$ NMR (200 MHz) $\delta 2.11(\mathrm{~s}, 3 \mathrm{H}), 5.05(\mathrm{~d}, J=0.2 \mathrm{~Hz}, 1 \mathrm{H}), 5.36(\mathrm{~d}, J=0.2 \mathrm{~Hz}, 1$ H), 7.25-7.51 (m, $9 \mathrm{H}) ;{ }^{13} \mathrm{C}$ NMR (50 MHz) $\delta 21.2,125.9,126.9$, 127.0, 127.3, 128.8, 140.1, 140.2, 140.8, 142.8; exact mass calcd for $\mathrm{C}_{15} \mathrm{H}_{14}$ 194.1096, found 194.1100 .

General Procedure for the Synthesis of Styrenes 7. To a solution of dithioacetal $3(1 \mathrm{mmol}), \mathrm{NiCl}_{2}\left(\mathrm{PPh}_{8}\right)_{2}(0.05 \mathrm{mmol})$, and benzene $(10 \mathrm{~mL})$ was added, in one portion, MeMgI $(10 \mathrm{~mL}$ of a $0.3 \mathrm{M}$ solution in $\mathrm{Et}_{2} \mathrm{O}, 3 \mathrm{mmol}$ ). The mixture was refluxed for $16 \mathrm{~h}$. The mixture was then poured into saturated aqueous $\mathrm{NH}_{4} \mathrm{Cl}$ and was extracted with $\mathrm{Et}_{2} \mathrm{O}(2 \times 20 \mathrm{~mL})$. The combined

(33) Greenwald, R.; Chaykovsky, M.; Corey, E. J. J. Org. Chem. 1963, $28,1128$.

(34) Tanimoto, I.; Kushioka, K.; Maruyama, K. J. Chem. Res., Synop. $1979,405$.

(35) Mowry, D. T.; Dazzi, J.; Renoll, M.; Shortridge, R. W. J. Am. Chem. Soc. 1948, 70, 1916. extracts were washed sequentially with $10 \%$ aqueous $\mathrm{NaOH}$ (2 $\times 20 \mathrm{~mL})$ and water $(2 \times 20 \mathrm{~mL})$ and were dried $\left(\mathrm{MgSO}_{4}\right)$. The solvent was evaporated in vacuo, and the residue was purified by column chromatography on silica gel (hexane) to afford the corresponding styrene.

2-[(Trimethylsilyl)methyl]styrene (12a): IR (neat) $\nu$ 3069, $3027,2960,2900,1628,1603,1483,1451,1419,1253,1215,1188$, $1156,1048,990,910,850,768,692 \mathrm{~cm}^{-1}$; ${ }^{1} \mathrm{H}$ NMR $(250 \mathrm{MHz}) \delta$ $0.03(\mathrm{~s}, 9 \mathrm{H}), 2.22(\mathrm{~s}, 2 \mathrm{H}) 5.27(\mathrm{~d}, J=11.0 \mathrm{~Hz}, 1 \mathrm{H}), 5.64(\mathrm{~d}, J$ $=17.0 \mathrm{~Hz}, 1 \mathrm{H}), 6.88-7.17(\mathrm{~m}, 4 \mathrm{H}), 7.48-7.52(\mathrm{~m}, 1 \mathrm{H}) ; \mathrm{MS} \mathrm{m} / \mathrm{z}$ 190. Anal. Calcd for $\mathrm{C}_{12} \mathrm{H}_{18}$ Si: $\mathrm{C}, 75.72 ; \mathrm{H}, 9.53$. Found: $\mathrm{C}, 75.33$; H, 9.15 .

3-[(Trimethylsilyl)methyl]styrene (12b): ${ }^{36}$ IR (neat) $\nu 3060$, $3040,2960,2900,1632,1600,1580,1485,1416,1250,1162,1078$, $990,905,890,800,695 \mathrm{~cm}^{-1}$; ${ }^{1} \mathrm{H}$ NMR $(250 \mathrm{MHz}) \delta 0.03(\mathrm{~s}, 9 \mathrm{H})$, 2.11 (s, $2 \mathrm{H}$ ), 5.24 (d, $J=11.0 \mathrm{~Hz}, 1 \mathrm{H}), 5.75$ (d, $J=17.0 \mathrm{~Hz}, 1$ H), 6.71 (dd, $J=11.0,17.0 \mathrm{~Hz}, 1 \mathrm{H}$ ), 6.91-7.24 (m, $4 \mathrm{H}$ ); $\mathrm{MS} \mathrm{m} / \mathrm{z}$ 190. Anal. Calcd for $\mathrm{C}_{12} \mathrm{H}_{18} \mathrm{Si}$ : C, 75.72; $\mathrm{H}, 9.53$. Found: $\mathrm{C}, 75.57$; H, 9.10.

2-[2-[(Trimethylsilyl)methyl]phenyl]dithiolane (11a). To a stirred solution of $10 \mathrm{a}(780 \mathrm{mg}, 2.99 \mathrm{mmol}), \mathrm{PdCl}_{2}\left(\mathrm{PPh}_{3}\right)_{2}(110$ $\mathrm{mg}, 0.16 \mathrm{mmol})$, and benzene $\left(20 \mathrm{~mL}\right.$ ) was added $\mathrm{Me}_{3} \mathrm{SiCH}_{2} \mathrm{MgCl}$ ( $20 \mathrm{~mL}$ of a $0.5 \mathrm{M}$ solution in $\mathrm{Et}_{2} \mathrm{O}, 10 \mathrm{mmol}$ ). The mixture was refluxed for $16 \mathrm{~h}$. The mixture was then poured into saturated aqueous $\mathrm{NH}_{4} \mathrm{Cl}$ and extracted with $\mathrm{Et}_{2} \mathrm{O}(2 \times 30 \mathrm{~mL})$. The combined extracts were washed with water $(2 \times 30 \mathrm{~mL})$ and were dried $\left(\mathrm{MgSO}_{4}\right)$. The solvent was evaporated in vacuo to afford $11 \mathrm{a}(790 \mathrm{mg}, 98 \%)$ as a yellow liquid. This was distilled to give $11 \mathrm{a}$ as colorless liquid: bp $140^{\circ} \mathrm{C}(0.4 \mathrm{~mm}) ; \operatorname{IR}$ (neat) $\nu 3064,3022$, $2959,1602,1480,1450,1422,1280,1250,1180,1156,842,769,741$, $692 \mathrm{~cm}^{-1} ;{ }^{1} \mathrm{H}$ NMR $\delta-0.02(\mathrm{~s}, 9 \mathrm{H}), 2.16(\mathrm{~s}, 2 \mathrm{H}), 3.21-3.47(\mathrm{~m}$ $4 \mathrm{H}), 5.72(\mathrm{~s}, 1 \mathrm{H}), 6.84-7.06(\mathrm{~m}, 4 \mathrm{H}) ; \mathrm{MS} m / z 268$. Anal. Calcd for $\mathrm{C}_{13} \mathrm{H}_{20} \mathrm{~S}_{2} \mathrm{Si}$ : C, 58.19; H, 7.52. Found: C, 57.75; H, 7.49.

2-[3-[(Trimethylsilyl)methyl]phenyl]dithiane (11b). A mixture of $10 \mathrm{~b}(830 \mathrm{mg}, 3.02 \mathrm{mmol}), \mathrm{PdCl}_{2}\left(\mathrm{PPh}_{3}\right)_{2}(108 \mathrm{mg}, 0.15$ $\mathrm{mmol}$ ), benzene $(20 \mathrm{~mL})$, and $\mathrm{Me}_{3} \mathrm{SiCH}_{2} \mathrm{MgCl}(20 \mathrm{~mL}$ of a 0.5 $\mathrm{M}$ solution in $\mathrm{Et}_{2} \mathrm{O}, 10 \mathrm{mmol}$ ) was treated in the same manner as described above to give $11 \mathrm{~b}(839 \mathrm{mg}, 99 \%)$ : bp $155^{\circ} \mathrm{C}(0.3$ mm); IR (neat) $\nu 3060,3030,2959,2900,1664,1601,1485,1280$, $1250,1160,1074,950,894,850,762,750,700 \mathrm{~cm}^{-1} ;{ }^{1} \mathrm{H}$ NMR $\delta-0.01$ (s, $9 \mathrm{H}), 1.83-2.19(\mathrm{~m}, 4 \mathrm{H}), 2.85-3.18(\mathrm{~m}, 4 \mathrm{H}), 5.11(\mathrm{~s}, 1 \mathrm{H})$ 6.90-7.24 (m, $4 \mathrm{H})$; MS $m / z$ 282. Anal. Calcd for $\mathrm{C}_{14} \mathrm{H}_{22} \mathrm{~S}_{2} \mathrm{Si}$ : C, 59.52; H, 7.85. Found: C, 59.57; H, 7.70.

2,2-Dimethyl-1-methyleneindan (9). According to the general procedure described above, a mixture of $8(251 \mathrm{mg}, 1.06 \mathrm{mmol})$ and $\mathrm{NiCl}_{2}\left(\mathrm{PPh}_{3}\right)_{2}(59 \mathrm{mg}, 0.09 \mathrm{mmol})$ in benzene $(5 \mathrm{~mL})$ was allowed to react with $\mathrm{MeMgI}\left(4.0 \mathrm{~mL}, 1 \mathrm{M}\right.$ in Et $\mathrm{t}_{2} \mathrm{O}, 4.0 \mathrm{mmol}$ ) under refluxing conditions for $16 \mathrm{~h}$ to give 9 as a colorless liquid (131 mg, 78\%): IR (neat) $\nu 3034,2862,1631,1584,1324,1161$, $1005,886,771,723 \mathrm{~cm}^{-1} ;{ }^{1} \mathrm{H}$ NMR (250 MHz) $\delta 1.22(\mathrm{~s}, 6 \mathrm{H}), 2.82$ (s, $2 \mathrm{H}), 4.92(\mathrm{~s}, 1 \mathrm{H}), 5.44(\mathrm{~s}, 1 \mathrm{H}), 7.18-7.20(\mathrm{~m}, 3 \mathrm{H}), 7.45-7.49$ $(\mathrm{m}, 1 \mathrm{H}) ;{ }^{13} \mathrm{C}$ NMR $\delta 29.4,42.6,47.1,100.9,121.1,125.3,126.5$, $128.5,140.4,143.5,160.1$; exact mass calcd for $\mathrm{C}_{12} \mathrm{H}_{14}$ 158.1085, found 158.1080 .

4-Methyl-1,2-dihydronaphthalene (14b). In a manner similar to that described in the general procedure, a mixture of $13 \mathrm{~b}$ (117 $\mathrm{mg}, 0.53 \mathrm{mmol}), \mathrm{NiCl}_{2}\left(\mathrm{PPh}_{3}\right)_{2}(35.2 \mathrm{mg}, 0.054 \mathrm{mmol}), \mathrm{MeMgI}(2$ $\mathrm{mL}$ of a $1 \mathrm{M}$ solution in $\left.\mathrm{Et}_{2} \mathrm{O}, 2 \mathrm{mmol}\right)$, and benzene $(1 \mathrm{~mL})$ was stirred at room temperature for $15 \mathrm{~h}$ to afford $14 \mathrm{~b}^{37}(46 \mathrm{mg}, 60 \%)$ : IR (neat) $\nu 3035,2950,1582,1239,1204,978 \mathrm{~cm}^{-1} ;{ }^{1} \mathrm{H}$ NMR $(60$ $\mathrm{MHz}) \delta 1.93-2.93(\mathrm{~m}, 7 \mathrm{H}, \mathrm{br} \mathrm{s}$ at 2.01$), 5.62-5.90(\mathrm{~m}, 1 \mathrm{H})$, $7.00-7.30(\mathrm{~m}, 4 \mathrm{H}) ; \mathrm{MS} m / z$ (relative intensity) $145\left(\mathrm{M}^{+}+1,7.1\right)$, $144\left(\mathrm{M}^{+}, 55.0\right), 129\left(\mathrm{M}-\mathrm{CH}_{3}, 100.0\right), 115(14.7)$; exact mass calcd for $\mathrm{C}_{11} \mathrm{H}_{12}$ 144.0939, found 144.0946.

3-Methyl-1 $\boldsymbol{H}$-indene (14a). In a manner similar to that described in the general procedure, a mixture of $13 \mathrm{a}(210 \mathrm{mg}, 1.0$ $\mathrm{mmol}), \mathrm{NiCl}_{2}\left(\mathrm{PPh}_{3}\right)_{2}(30 \mathrm{mg}, 0.05 \mathrm{mmol}), \mathrm{MeMgI}(4.0 \mathrm{~mL}$ of a $1 \mathrm{M}$ solution in $\mathrm{Et}_{2} \mathrm{O}, 4.0 \mathrm{mmol}$ ), and benzene $(2 \mathrm{~mL})$ was stirred at room temperature for $16 \mathrm{~h}$ to give $14 \mathrm{a}^{38}(90 \mathrm{mg}, 69 \%)$ : IR (neat) $\nu 3030,2946,1582,1238,978,763 \mathrm{~cm}^{-1} ;{ }^{1} \mathrm{H}$ NMR $(60 \mathrm{MHz}) \delta$

(36) Nagasaki, Y.; Tsuruta, T. Makromol. Chem. 1986, 187, 1583. (37) Valkovich, P. B.; Conger, J. L.; Castiello, F. A.; Brodie, T. D.; Weber, W. P. J. Am. Chem. Soc. 1975, 97, 901.

(38) Parham, W. E.; Reiff, H. E.; Swartzentruber, P. J. Am. Chem. Soc. $1956,78,1437$. 
2.03-2.30 (br s, 3 H), 3.10-3.43 (br s, 2 H), 6.10 (br s, $1 \mathrm{H}) ; 6.93-7.53$ (m, $4 \mathrm{H}) ; \mathrm{MS} m / z$ (relative intensity) $131\left(\mathrm{M}^{+}+1,14.1\right), 130\left(\mathrm{M}^{+}\right.$, 100.0), $115\left(\mathrm{M}-\mathrm{CH}_{3}, 50.1\right), 77$ (11.4).

2-(4-Biphenylyl)propene (5). In a manner similar to that described in the general procedure, a mixture of $3 \mathrm{a}(266 \mathrm{mg}, 0.98$ $\mathrm{mmol}), \mathrm{NiCl}_{2}\left(\mathrm{PPh}_{3}\right)_{2}(42 \mathrm{mg}, 0.06 \mathrm{mmol}), \mathrm{MeMgI}(3 \mathrm{~mL}$ of a 1 $\mathrm{M}$ solution in $\left.\mathrm{Et}_{2} \mathrm{O}, 3 \mathrm{mmol}\right)$, and benzene $(5 \mathrm{~mL})$ was heated under reflux for $18 \mathrm{~h}$ to give $5(180 \mathrm{mg}, 95 \%)$ : $\mathrm{mp} 117-118^{\circ} \mathrm{C}$ The spectra of 5 were identical with those of an authentic sample.

General Procedure for the Reaction of 3 with Allylmagnesium Halides. To a solution of allyl Grignard reagent [freshly prepared from $\mathrm{Mg}$ ( $8 \mathrm{~g}$-atom), allyl halide $(8 \mathrm{mmol})$, and $\left.\mathrm{Et}_{2} \mathrm{O}(10 \mathrm{~mL})\right]$ was added, under $\mathrm{N}_{2}$, a solution of dithioacetal (1 mmol) and either $\mathrm{NiCl}_{2}$ (dppe) or $\mathrm{NiCl}_{2}\left(\mathrm{PPh}_{3}\right)_{2}(0.05 \mathrm{mmol})$ in benzene $(8 \mathrm{~mL})$ in one portion. The mixture was heated under reflux for $16 \mathrm{~h}$. The cooled solution was then poured into saturated aqueous $\mathrm{NH}_{4} \mathrm{Cl}$ and was extracted with $\mathrm{Et}_{2} \mathrm{O}(2 \times 20 \mathrm{~mL})$. The combined extracts were washed sequentially with $10 \%$ aqueous $\mathrm{NaOH}(2 \times 20 \mathrm{~mL})$ and water $(2 \times 20 \mathrm{~mL})$ and were dried $\left(\mathrm{MgSO}_{4}\right)$. The solvent was evaporated in vacuo, and the residue was purified by column chromatography on silica gel (hexane) to afford the corresponding 1,4-diene. An analytical sample was obtained by recrystallization, distillation, or preparative GC (6-ft SE30 column).

2-(4-Biphenylyl)-1,4-pentadiene (32a). In a manner similar to that described in the general procedure, a mixture of $3 \mathbf{a}$ (272 $\mathrm{mg}, 1.0 \mathrm{mmol})$ and benzene $(8 \mathrm{~mL})$ was treated in the presence of $\mathrm{NiCl}_{2}$ (dppe) (32.7 mg, $0.05 \mathrm{mmol}$ ) with $\mathrm{CH}_{2}=\mathrm{CHCH}_{2} \mathrm{MgBr}$ $(8 \mathrm{mmol})$ to give $32 \mathrm{a}(101 \mathrm{mg}, 73 \%)$ : $\mathrm{mp} 43-45^{\circ} \mathrm{C}$; IR (neat), $\nu 3029,2925,1637,1601,1485,1446,843,770,740,697 \mathrm{~cm}^{-1} ;{ }^{1} \mathrm{H}$ NMR $\delta 3.28(\mathrm{~d}, J=6.0 \mathrm{~Hz}, 2 \mathrm{H}), 5.05-5.19(\mathrm{~m}, 3 \mathrm{H}), 5.46(\mathrm{br} \mathrm{s}$, $1 \mathrm{H}), 5.80-6.05(\mathrm{~m}, 1 \mathrm{H}), 7.35-7.60(\mathrm{~m}, 9 \mathrm{H}) ;{ }^{13} \mathrm{C}$ NMR $\delta 39.4,113.2$, $116.5,126.9,127.2,128.7,136.2,139.7,140.2,140.6,145.7$; exact mass calcd for $\mathrm{C}_{17} \mathrm{H}_{16} 220.1252$, found 220.1254 .

2-(2-Naphthyl)-1,4-pentadiene (32b). In a manner similar to that described in the general procedure in which $\mathrm{NiCl}_{2}$ (dppe) was the catalyst, $3 \mathbf{b}$ ( $246 \mathrm{mg}, 1.0 \mathrm{mmol}$ ) was converted to $32 \mathrm{~b}$ (149 $\mathrm{mg}, 77 \%$ ): an oil; IR (neat) $\nu 3034,2925,803,779 \mathrm{~cm}^{-1} ;{ }^{1} \mathrm{H}$ NMR $\delta 3.22(\mathrm{~d}, J=5.8 \mathrm{~Hz}, 2 \mathrm{H}), 5.05-5.14(\mathrm{~m}, 3 \mathrm{H}), 5.42(\mathrm{br} \mathrm{s}, 1 \mathrm{H})$, $5.75-6.00(\mathrm{~m}, 1 \mathrm{H}), 7.25-8.04(\mathrm{~m}, 7 \mathrm{H}) ;{ }^{13} \mathrm{C} \mathrm{NMR} \delta 30.8,42.8,115.9$ 116.5, 125.0, 125.1, 125.6, 127.2, 128.2, 131.1, 133.7, 135.6; exact mass calcd for $\mathrm{C}_{15} \mathrm{H}_{14}$ 194.1095, found 194.1088.

2-(2-Fluorenyl)-1,4-pentadiene (32c). In a manner similar to that described in the general procedure in which $\mathrm{NiCl}_{2}$ (dppe) was the catalyst, $3 \mathrm{c}$ (284 $\mathrm{mg}, 1.0 \mathrm{mmol})$ was converted to $32 \mathrm{c} \mathrm{(151}$

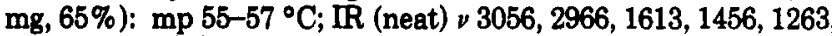
$802,740 \mathrm{~cm}^{-1} ;{ }^{1} \mathrm{H}$ NMR 3.32 (d, $\left.J=6.6 \mathrm{~Hz}, 2 \mathrm{H}\right), 3.88(\mathrm{~s}, 2 \mathrm{H})$, 5.09-5.19 (m, 3 H), 5.45 (br \&, $1 \mathrm{H}), 5.84-6.04(\mathrm{~m}, 1 \mathrm{H}), 7.25-7.85$ $(\mathrm{m}, 7 \mathrm{H}) ;{ }^{13} \mathrm{C}$ NMR $\delta 36.9,76.4,112.8,116.4,119.5,119.9,122.6$, $124.8,124.9,126.6,126.7,136.3,139.5,141.1,141.4,143.3,143.4$ 146.5; exact mass calcd for $\mathrm{C}_{18} \mathrm{H}_{14} 232.1252$, found 232.1255 .

2-(4-Tolyl)-1,4-pentadiene (32d). In a manner similar to that described in the general procedure, $3 \mathrm{~d}(210 \mathrm{mg}, 1 \mathrm{mmol})$ was allowed to react in the presence of $\mathrm{NiCl}_{2}\left(\mathrm{PPh}_{3}\right)_{2}(32.7 \mathrm{mg}, 0.05$ mmol) with $\mathrm{CH}_{2}=\mathrm{CHCH}_{2} \mathrm{MgBr}(8 \mathrm{mmol})$ to give $32 \mathrm{~d}(130 \mathrm{mg}$, $82 \%$ ): IR (neat) $\nu 3081,2978,1624,1512,1433,1121,893,824$, $734 ;{ }^{1} \mathrm{H}$ NMR $\delta 2.34(\mathrm{~s}, 3 \mathrm{H}), 3.24(\mathrm{~d}, J=6.4 \mathrm{~Hz}, 2 \mathrm{H}), 5.05-5.15$ $(\mathrm{m}, 3 \mathrm{H}), 5.36(\mathrm{br} \mathrm{s}, 1 \mathrm{H}), 5.80-6.00(\mathrm{~m}, 1 \mathrm{H}), 7.13(\mathrm{~d}, J=8.0 \mathrm{~Hz}$ $2 \mathrm{H}), 7.33$ (d, $J=8.0 \mathrm{~Hz}, 2 \mathrm{H}) ;{ }^{13} \mathrm{C}$ NMR $\delta 19.7,39.5,112.3,116.3$, $125.8,128.9,136.3,137.2,148.1$.

2-(2-Toly1)-1,4-pentadiene (32e). In a manner similar to that described in the general procedure, $3 \mathrm{e}(210 \mathrm{mg}, 1.0 \mathrm{mmol})$ was allowed to react in the presence of $\mathrm{NiCl}_{2}\left(\mathrm{PPh}_{3}\right)_{2}(32.7 \mathrm{mg}, 0.05$ mmol) with $\mathrm{CH}_{2}=\mathrm{CHCH}_{2} \mathrm{MgBr}(8 \mathrm{mmol})$ to give a $4: 1$ mixture of 32e and 4-(2-tolyl)-1,3-pentadiene (33e) $)^{14 c}(128 \mathrm{mg}, 82 \%)$. The two isomers were separated by preparative gas chromatography. 32e: IR (neat) v 3076, 2923, 1638, 1485, 1430, $909,766,730 \mathrm{~cm}^{-1}$ ${ }^{1} \mathrm{H}$ NMR $\delta 2.29(\mathrm{~s}, 3 \mathrm{H}), 3.55(\mathrm{~d}, J=6.0 \mathrm{~Hz}, 2 \mathrm{H}), 4.91-5.20(\mathrm{~m}$ $3 \mathrm{H}), 5.73-5.94(\mathrm{~m}, 1 \mathrm{H}), 7.05-7.16(\mathrm{~m}, 4 \mathrm{H}) ;{ }^{13} \mathrm{C}$ NMR $\delta 19.6,42.0$,

$114.4,116.4,125.3,126.6,128.3,130.0,134.7,135.6,142.8,148.3$.

(Z)-Phenyl-1,4-hexadiene (32g). In a manner similar to that described in the general procedure, $3 \mathrm{~g}(198 \mathrm{mg}, 1.0 \mathrm{mmol})$ was allowed to react in the presence of $\mathrm{NiCl}_{2}$ (dppe) $(26.4 \mathrm{mg}, 0.05$ mmol) with $\mathrm{CH}_{2}=\mathrm{CHCH}_{2} \mathrm{MgBr}(8 \mathrm{mmol})$ to give $32 \mathrm{~g}$ (112 $\mathrm{mg}$, $71 \%):{ }^{1} \mathrm{H}$ NMR $\delta 1.60(\mathrm{~d} J=6.9 \mathrm{~Hz}, 3 \mathrm{H}), 3.25(\mathrm{~d}, J=5.7 \mathrm{~Hz}$ $2 \mathrm{H}), 4.96-5.11(\mathrm{~m}, 2 \mathrm{H}), 5.76-5.98(\mathrm{~m}, 1 \mathrm{H}), 7.16-7.39(\mathrm{~m}, 4 \mathrm{H})$;
${ }^{13} \mathrm{C}$ NMR $\delta 14.2,34.1,115.1,124.2,125.9,126.4,128.1,135.6,137.6$; exact mass calcd for $\mathrm{C}_{12} \mathrm{H}_{14} 158.1095$, found 158.1091 .

3-Allyl-1H-indene (32i). In a manner similar to that described in the general procedure in which $\mathrm{NiCl}_{2}$ (dppe) was the catalyst, $13 \mathrm{a}(208 \mathrm{mg}, 1.0 \mathrm{mmol})$ was converted to $32 \mathrm{i}(134 \mathrm{mg}, 86 \%)$ : IR (neat) $\nu 3052,2920,11455,1089,758 \mathrm{~cm}^{-1} ;{ }^{1} \mathrm{H}$ NMR $\delta 2.34-3.30$ $(\mathrm{m}, 4 \mathrm{H}), 5.13(\mathrm{~d}, J=10 \mathrm{~Hz}, 1 \mathrm{H}), 5.19(\mathrm{~d}, J=18 \mathrm{~Hz}, 1 \mathrm{H})$, 5.94-6.14 (m, $1 \mathrm{H}), 6.24(\mathrm{~s}, 1 \mathrm{H}), 7.10-7.55(\mathrm{~m}, 4 \mathrm{H}) ;{ }^{13} \mathrm{C} \mathrm{NMR}$ $\delta 32.4,77.2,116.2,119.1,123.7,124.5,125.9,128.9,135.6,142.4$, 144.5, 145.1; exact mass calcd for $\mathrm{C}_{12} \mathrm{H}_{12} 156.0939$, found 156.0936 .

2-Phenyl-1,4-hexadiene (32f). In a manner similar to that described in the general procedure, $3 f(196 \mathrm{mg}, 1.0 \mathrm{mmol})$ was allowed to react in the presence of $\mathrm{NiCl}_{2}$ (dppe) (26.4 $\mathrm{mg}, 0.05$ mmol) with $\mathrm{MeCH}=\mathrm{CHCH}_{2} \mathrm{MgBr}(8 \mathrm{mmol})$ to give $32 \mathrm{f}(106 \mathrm{mg}$, $73 \%$ ): ${ }^{1} \mathrm{H}$ NMR $\delta 1.86$ (br s, $3 \mathrm{H}$ ), 3.20 (br s, $2 \mathrm{H}, 4.4 \%$ NOE enhancement upon irradiation at $\delta 1.86), 5.08$ (br s, $1 \mathrm{H}$ ), 5.34 (br s, $1 \mathrm{H}), 5.53(\mathrm{~m}, 2 \mathrm{H}), 7.22-7.46(\mathrm{~m}, 5 \mathrm{H}) ;{ }^{13} \mathrm{C}$ NMR $\delta 14.5$, $17.9,112.6,125.9,126.9,127.3,128.2,128.6,141.1,147.1$; exact mass calcd for $\mathrm{C}_{12} \mathrm{H}_{14}$ 158.1095, found 158.1099.

2-Methyl-4-phenyl-1,4-hexadiene (32h). In a manner similar to that described in the general procedure, $3 \mathrm{~g}(210 \mathrm{mg}, 1.0 \mathrm{mmol})$ was allowed to react in the presence of $\mathrm{NiCl}_{2}$ (dppe) (26.4 mg, 0.05 mmol) with $\mathrm{CH}_{2}=\mathrm{C}(\mathrm{Me}) \mathrm{CH}_{2} \mathrm{MgBr}(8 \mathrm{mmol})$ to give $32 \mathrm{~h}$ (106 mg, $62 \%)$ : ${ }^{1} \mathrm{H}$ NMR $\delta 1.76(\mathrm{~d}, J=8.0 \mathrm{~Hz}, 3 \mathrm{H}), 1.79(\mathrm{~s}, 3 \mathrm{H}), 3.17$ (br s, $2 \mathrm{H}), 4.70$ (br s, $1 \mathrm{H}), 4.75(\mathrm{br} \mathrm{s}, 1 \mathrm{H}), 5.96(\mathrm{q}, J=8.0 \mathrm{~Hz}$, $1 \mathrm{H}), 7.18-7.35$ (m, $5 \mathrm{H})$; ${ }^{13} \mathrm{C}$ NMR $\delta 14.4,22.9,37.9,110.8,124.8$, $125.9,126.4,128.1,137.8,142.8,143.6$; exact mass calcd for $\mathrm{C}_{12} \mathrm{H}_{14}$ 158.1095 , found 158.1091

3-Methallyl-1 $\boldsymbol{H}$-indene (32j). In a manner similar to that described in the general procedure, $13 \mathrm{a}(208 \mathrm{mg}, 1.0 \mathrm{mmol})$ was allowed to react in the presence of $\mathrm{NiCl}_{2}$ (dppe) $(26.4 \mathrm{mg}, 0.05$ mmol) with $\mathrm{CH}_{2}=\mathrm{C}(\mathrm{Me}) \mathrm{CH}_{2} \mathrm{MgBr}(8 \mathrm{mmol})$ to give $32 \mathrm{j}$ (126 mg, $74 \%):{ }^{1} \mathrm{H}$ NMR $\delta 1.77(\mathrm{~s}, 3 \mathrm{H}), 3.29(\mathrm{~s}, 2 \mathrm{H}), 3.34(\mathrm{~s}, 2 \mathrm{H}), 4.82$ (br s, $2 \mathrm{H}), 6.24$ (br s, $1 \mathrm{H}), 7.15-7.24(\mathrm{~m}, 4 \mathrm{H}) ;{ }^{13} \mathrm{C} \mathrm{NMR} \delta 36.9$, $37.8,112.2,119.6,123.7,124.5,126.0,130.1,141.9,143.4,144.6$, 145.4; exact mass calcd for $\mathrm{C}_{12} \mathrm{H}_{14} 170.1095$, found 170.1098 .

Reaction of 2-Benzyl-2-phenyl-1,3-dithiolane (15) with MeMgI. In a manner similar to that described in the general procedure, a mixture of $15(260 \mathrm{mg}, 0.95 \mathrm{mmol}), \mathrm{NiCl}_{2}\left(\mathrm{PPh}_{3}\right)_{2}(32$ $\mathrm{mg}, 0.05 \mathrm{mmol}), \mathrm{MeMgI}$ ( $3 \mathrm{~mL}$ of a $1 \mathrm{M}$ solution in $\mathrm{Et}_{2} \mathrm{O}, 3 \mathrm{mmol}$ ), and benzene $(5 \mathrm{~mL})$ was stirred at room temperature for $16 \mathrm{~h}$ to yield a 2:1 mixture of $(E)$-1,2-diphenylpropene (16) and 2,3-diphenylpropene $(17,173 \mathrm{mg}, 94 \%)$. The $16: 17$ ratio was determined by ${ }^{1} \mathrm{H}$ NMR analysis. The two olefins were separated by preparative TLC (hexane). 16:39 IR (neat) ע 3052, 2951, 1599, 1496, $1442,1361,1072,908,753,700 \mathrm{~cm}^{-1} ;{ }^{1} \mathrm{H}$ NMR $(60 \mathrm{MHz}) \delta 2.20$ $(\mathrm{d}, J=2 \mathrm{~Hz}, 3 \mathrm{H}), 6.75(\mathrm{q}, J=2 \mathrm{~Hz}, 1 \mathrm{H}), 7.03-7.56(\mathrm{~m}, 10 \mathrm{H})$; MS $m / z$ (relative intensity) $195\left(\mathbf{M}^{+}+1,7.4\right), 194\left(\mathrm{M}^{+}, 100.0\right)$, $177(25.3), 103(10.6), 91$ (7.0). 17:40 IR (neat) v 3050, 2951, 1590, $1489,1360,1077,755,698 \mathrm{~cm}^{-1} ;{ }^{1} \mathrm{H}$ NMR (60 MHz) $\delta 3.77$ (br s, $2 \mathrm{H}), 4.95$ (br s, $1 \mathrm{H}$ ), 5.42 (br s, $1 \mathrm{H}), 7.04-7.55$ (m, $10 \mathrm{H}$ ); MS $m / z$ (relative intensity) $195\left(\mathrm{M}^{+}+1,8.6\right), 194\left(\mathrm{M}^{+}, 100\right), 91(67.3)$.

Reaction of 21 a with $\mathrm{MeMgI}$ Catalyzed by $\mathrm{NiCl}_{2}\left(\mathrm{PPh}_{3}\right)_{2}$. $\mathrm{MeMgI}$ ( $3 \mathrm{~mL}$ of a $1 \mathrm{M}$ solution in $\mathrm{Et}_{2} \mathrm{O}, 3 \mathrm{mmol}$ ) was added to a solution of sulfide $21 \mathrm{a}(45.4 \mathrm{mg}, 0.20 \mathrm{mmol}), \mathrm{NiCl}_{2}\left(\mathrm{PPh}_{3}\right)_{2}(9.7$ $\mathrm{mg}, 0.015 \mathrm{mmol}$ ), and benzene $(2 \mathrm{~mL})$. The mixture was refluxed for 3 days. After the usual workup, 21a was recovered (42 mg, $93 \%$ ).

Reaction of 2,2-Diphenyl-3-thiabutane (21b) with MeMgI Catalyzed by $\mathrm{NiCl}_{2}\left(\mathrm{PPh}_{3}\right)_{2}$. To a solution of $21 \mathrm{~b}(142 \mathrm{mg}, 0.59$ $\mathrm{mmol}), \mathrm{NiCl}_{2}\left(\mathrm{PPh}_{3}\right)_{2}(20.4 \mathrm{mg}, 0.03 \mathrm{mmol})$, and $\mathrm{THF}(5 \mathrm{~mL})$ under $\mathrm{N}_{2}$ was added $\mathrm{MeMgI}(2 \mathrm{~mL}, 2 \mathrm{mmol}$ ) via syringe. The mixture was refluxed for $16 \mathrm{~h}$. After the usual workup (treatment with saturated aqueous $\mathrm{NH}_{4} \mathrm{Cl}$, extraction, washing with $10 \%$ aqueous $\mathrm{NaOH}$ ) and chromatographic purification, 2a was obtained (43 $\mathrm{mg}, 41 \%$ ). Its spectra were identical with those of an authentic sample.

4-(4-Biphenylyl)-3-thiapentane-1-thiol (22). A mixture of $3 \mathrm{a}(0.5 \mathrm{~g}, 1.84 \mathrm{mmol})$, tri- $n$-butyltin hydride $(0.7 \mathrm{~g}, 2.41 \mathrm{mmol})$, and dibenzoyl peroxide ( $10 \mathrm{mg}, 0.04 \mathrm{mmol}$ ) was heated at $80-90$ ${ }^{\circ} \mathrm{C}$ for $3 \mathrm{~h}$. After it cooled to room temperature, the components of the mixture were separated by flash chromatography (hexane).

(39) Kingsbury, C. A.; Draney, D.; Sopchik, A.; Rissler, W.; Durham, D. J. Org. Chem. 1976, 41, 3863 .

(40) Michman, M.; Zeiss, H. H. J. Organomet. Chem. 1968, 15, 139. 
Compound 22 was obtained as a colorless oil $(0.23 \mathrm{~g}, 33 \%)$ : IR (neat) y 3034, 2910, 1595, 1480, 1455, 1420, 1380, 1270, 1155, 1100, $900,842,725 \mathrm{~cm}^{-1}$; ${ }^{1} \mathrm{H}$ NMR $(60 \mathrm{MHz}) \delta 1.56(\mathrm{~d}, J=7 \mathrm{~Hz}$, also contains a thiol proton, $4 \mathrm{H}), 2.42-2.72(\mathrm{~m}, 4 \mathrm{H}), 3.98(\mathrm{q}, J=7$ $\mathrm{Hz}, 1 \mathrm{H}$ ), 7.15-7.72 (m, $9 \mathrm{H})$; exact mass calcd for $\mathrm{C}_{16} \mathrm{H}_{18} \mathrm{~S}_{2}$ 274.0844 , found 274.0846 .

Reaction of 22 with $\mathrm{MeMgI}$ Catalyzed by $\mathrm{NiCl}_{2}\left(\mathrm{PPh}_{3}\right)_{2}$. To a mixture of $22(50.0 \mathrm{mg}, 0.18 \mathrm{mmol}), \mathrm{NiCl}_{2}\left(\mathrm{PPh}_{3}\right)_{2}(8.0 \mathrm{mg}$, $0.012 \mathrm{mmol})$, and benzene $(5 \mathrm{~mL})$ under $\mathrm{N}_{2}$ was added $\mathrm{MeMgI}$ $\left(0.8 \mathrm{~mL}\right.$ of a $1 \mathrm{M}$ solution in $\left.\mathrm{Et}_{2} \mathrm{O}, 0.8 \mathrm{mmol}\right)$. The mixture was stirred at room temperature for $24 \mathrm{~h}$ and then was quenched with saturated aqueous $\mathrm{NH}_{4} \mathrm{Cl}$. The two liquid layers were separated. The aqueous layer was extracted with $\mathrm{Et}_{2} \mathrm{O}$. The combined organic layers were washed with $10 \%$ aqueous $\mathrm{NaOH}$ and water and were dried $\left(\mathrm{Na}_{2} \mathrm{SO}_{4}\right)$. After evaporation of the solvent in vacuo, the residue was purified by column chromatography on silica gel (hexane) to give $7 \mathrm{~g}(20 \mathrm{mg}, 61 \%)$ : $\mathrm{mp} 122-123^{\circ} \mathrm{C}$ (lit. ${ }^{41}$ $\mathrm{mp} 119-119.5^{\circ} \mathrm{C}$ ). The spectra of $7 \mathrm{~g}$ and those of an authentic sample were identical.

Reaction of 1 with $i$-PrMgBr. In a manner similar to that described in the general procedure, a mixture of $1(262 \mathrm{mg}, 1.01$ mmol), $\mathrm{NiCl}_{2}\left(\mathrm{PPh}_{3}\right)_{2}$ (36 mg, $0.05 \mathrm{mmol}$ ), $i$-PrMgBr (1 M solution in $\mathrm{Et}_{2} \mathrm{O}, 3 \mathrm{~mL}, 3 \mathrm{mmol}$ ), and benzene ( $5 \mathrm{~mL}$ ) was stirred for 16 $h$ at room temperature to afford a $6.7: 1$ mixture of 1,1-diphenyl-2-methylpropane (25) and 1,1-diphenyl-2-methylpropene (26) $(158 \mathrm{mg}, 76 \%)$. The two compounds were separated by preparative TLC (hexane). 25: ${ }^{41}$ IR (neat) $\nu$ 3025, 2950, 1595, $1445,1382,1165,755,740,700 \mathrm{~cm}^{-1} ;{ }^{1} \mathrm{H}$ NMR $(60 \mathrm{MHz}) \delta 0.85$ (d, $J=6 \mathrm{~Hz}, 6 \mathrm{H}), 2.45(\mathrm{~m}, 1 \mathrm{H}), 3.37(\mathrm{~d}, J=11 \mathrm{~Hz}, 1 \mathrm{H}), 7.16$ (8, $10 \mathrm{H}) ; \mathrm{MS} m / z$ (relative intensity) $211\left(\mathrm{M}^{+}+1,1.9\right), 210\left(\mathrm{M}^{+}\right.$, 10.0), 167 (100.0), 152 (16.6), 115 (8.7), 91 (9.38). 26:43 IR (neat) $\nu 3050,3010,2900,1650,1595,1485,1435,754,685 \mathrm{~cm}^{-1} ;{ }^{1} \mathrm{H}$ NMR $(60 \mathrm{MHz}) \delta 2.21(\mathrm{~s}, 6 \mathrm{H}), 7.16(\mathrm{~s}, 10 \mathrm{H}) ; \mathrm{MS} m / z$ (relative intensity) $209\left(\mathrm{M}^{+}+1,2.4\right), 208\left(\mathrm{M}^{+}, 9.8\right), 193(100)$.

Reaction of 30 with Ethylmagnesium Bromide. The reaction of 30 (78.3 mg, $0.25 \mathrm{mmol})$ with $\mathrm{EtMgBr}(2 \mathrm{~mL}$ of a $1 \mathrm{M}$ solution in $\mathrm{Et}_{2} \mathrm{O}, 2 \mathrm{mmol}$ ) in toluene $(3 \mathrm{~mL})$ in the presence of $\mathrm{NiCl}_{2}\left(\mathrm{PPh}_{3}\right)_{2}(20 \mathrm{mg}, 0.03 \mathrm{mmol})$, performed in a manner similar to that described in the general procedure, gave the reduction product $31^{44}$ (31 mg, 56\%): bp $120^{\circ} \mathrm{C}(1 \mathrm{mmHg}$ Kugelrohr distillation); IR (neat) $\nu 3064,2960,1599,1522,1400,1250,1156$, $1011,845,777,692 \mathrm{~cm}^{-1} ;{ }^{1} \mathrm{H}$ NMR $(60 \mathrm{MHz}) \delta 0.08(\mathrm{~s}, 9 \mathrm{H}), 2.67$ $(\mathrm{s}, 2 \mathrm{H}), 7.13-8.23(\mathrm{~m}, 7 \mathrm{H}) ; \mathrm{MS} \mathrm{m} / 2$ (relative intensity) $214\left(\mathrm{M}^{+}\right.$, $0.84), 73$ (base peak).

Isolation of the Dibenzyl Bisthioether (31) of 1,2Ethanedithiol from the Reaction of 1 with MeMgI. A mixture of $1(285 \mathrm{mg}, 1.10 \mathrm{mmol}), \mathrm{MeMgI}\left(4 \mathrm{~mL}\right.$ of a $1 \mathrm{M}$ solution in $\mathrm{Et}_{2} \mathrm{O}$, $4 \mathrm{mmol}$ ), benzene $(5 \mathrm{~mL})$, and $\mathrm{NiCl}_{2}\left(\mathrm{PPh}_{3}\right)_{2}(60 \mathrm{mg}, 0.09 \mathrm{mmol})$ was refluxed for $10 \mathrm{~h}$. The mixture was quenched with $10 \%$ aqueous $\mathrm{NaOH}(5 \mathrm{~mL})$ and benzyl bromide $(400 \mathrm{mg}, 2.3 \mathrm{mmol})$. The mixture was then refluxed for $4 \mathrm{~h}$. After it cooled, it was

(41) Huber, W. F.; Renoll, M.; Rossow, A. G.; Mowry, D. T. J. Am. Chem. Soc. 1946, 68, 1109.

(42) Bunnett, J. F.; Gloor, B. F. J. Org. Chem. 1973, 38, 4156

(43) Incremona, J. H.; Martin, J. C. J. Am. Chem. Soc. 1970, 92, 627.

(44) Tamao, K.; Sumitani, K.; Kiso, Y.; Zembayashi, M.; Fujioka, A.; Kodama, S.-i.; Nakijima, I.; Minota, A.; Kumada, M. Bull. Chem. Soc. Jpn. 1976, 49, 1958. poured into water $(10 \mathrm{~mL})$. The two liquid layers were separated. The aqueous layer was extracted with $\mathrm{Et}_{2} \mathrm{O}(2 \times 20 \mathrm{~mL})$. The combined organic layers were washed with $10 \%$ aqueous $\mathrm{NaOH}$ $(10 \mathrm{~mL})$ and water $(2 \times 20 \mathrm{~mL})$ and were dried $\left(\mathrm{Na}_{2} \mathrm{SO}_{4}\right)$. After evaporation of the solvent in vacuo, the residue was purified by column chromatography on silica gel (hexane/EtOAc, 9:1) to give $31^{45}(129 \mathrm{mg}, 47 \%)$ : IR (neat) $\nu 3031,1600,1494,1452,1241,1196$, $1070,1028,768,697 \mathrm{~cm}^{-1}$; ${ }^{1} \mathrm{H}$ NMR (60 MHz) $\delta 2.53(\mathrm{~s}, 4 \mathrm{H}), 3.63$ $(\mathrm{s}, 4 \mathrm{H}), 7.20(\mathrm{~s}, 10 \mathrm{H}) ; \mathrm{MS} \mathrm{m} / \mathrm{z}$ (relative intensity) $276\left(\mathrm{M}^{+}+\right.$ 2, 0.5), $274\left(\mathrm{M}^{+}, 4.4\right), 91$ (base peak).

Detection of the Ethane Produced during the Reaction of $\mathrm{MeMgI}$ with $\mathrm{NiCl}_{2}\left(\mathrm{PPh}_{3}\right)_{2}$. To $\mathrm{NiCl}_{2}\left(\mathrm{PPh}_{3}\right)_{2}(0.5 \mathrm{~g}, 0.76$ mmol) under $\mathrm{N}_{2}$ were added, by syringe, benzene $(5 \mathrm{~mL})$ and $\mathrm{MeMgI}(1 \mathrm{~mL}$ of a $2.0 \mathrm{M}$ solution in ether, $2 \mathrm{mmol})$. A reaction took place immediately. Heat was liberated, and the mixture turned dark brown. A sample of the vapor above the liquid phase was removed with a gas-tight syringe and was subjected to GC-MS analysis (GC temperature, $31^{\circ} \mathrm{C}$; MS electron beam energy, 11 eV). A peak in the spectrum at $m / z 30$ was attributed to ethane.

Detection of the $\mathrm{Me}_{3} \mathrm{SiCH}_{2} \mathrm{CH}_{2} \mathrm{SiMe}_{3}$ Produced during the Reaction of $\mathbf{M e}_{3} \mathbf{S i C H}_{2} \mathbf{M g C l}$ with $\mathbf{N i C l}_{2}\left(\mathbf{P P h}_{3}\right)_{2}$. In a manner similar to that described above, $\mathrm{NiCl}_{2}\left(\mathrm{PPh}_{3}\right)_{2}(0.5 \mathrm{~g}, 0.76 \mathrm{mmol})$ in benzene $(10 \mathrm{~mL})$ was allowed to react with $\mathrm{Me}_{3} \mathrm{SiCH}_{2} \mathrm{MgCl}(3.0$ $\mathrm{mL}$ of a $2.0 \mathrm{M}$ solution in $\mathrm{Et}_{2} \mathrm{O}, 6.0 \mathrm{mmol}$ ). After the exothermic reaction subsided, the mixture was poured into saturated aqueous $\mathrm{NH}_{4} \mathrm{Cl}$ and was extracted with $\mathrm{Et}_{2} \mathrm{O}(3 \times 10 \mathrm{~mL})$. The combined extracts were washed with $10 \%$ aqueous $\mathrm{NaOH}(10 \mathrm{~mL})$, water $(10 \mathrm{~mL})$, and brine $(10 \mathrm{~mL})$ and were dried $\left(\mathrm{MgSO}_{4}\right)$. The dried extract was analyzed by GC-MS (GC temperature, $57^{\circ} \mathrm{C}$; MS electron beam energy, $11 \mathrm{eV}$ ). A peak in the spectrum at $\mathrm{m} / z$ 174 was attributed to $\mathrm{Me}_{3} \mathrm{SiCH}_{2} \mathrm{CH}_{2} \mathrm{SiMe}_{3}$.

Detection of the $\mathrm{Me}_{4} \mathrm{Si}$ Produced during the Reaction of $\mathrm{Me}_{3} \mathrm{SiCH}_{2} \mathbf{M g C l}$ with 1 in the Presence of $\mathrm{NiCl}_{2}\left(\mathrm{PPh}_{3}\right)_{2}$. Under $\mathrm{N}_{2}$, to a mixture of $1(523.7 \mathrm{mg}, 2.0 \mathrm{mmol}), \mathrm{NiCl}_{2}\left(\mathrm{PPh}_{3}\right)_{2}$ (71.3 $\mathrm{mg}, 0.11 \mathrm{mmol})$, and benzene $(15 \mathrm{~mL})$ was added, by syringe, $\mathrm{Me}_{3} \mathrm{SiCH}_{2} \mathrm{MgCl}\left(4.0 \mathrm{~mL}\right.$ of a $2 \mathrm{M}$ solution in $\left.\mathrm{Et}_{2} \mathrm{O}, 8 \mathrm{mmol}\right)$. The mixture was refluxed for $16 \mathrm{~h}$. The solvent was then removed by distillation. The distillate was analyzed by GC-MS analysis (GC temperature, $45^{\circ} \mathrm{C}$; MS electron beam energy, $11 \mathrm{eV}$ ). A peak in the spectrum at $m / z 88$ was attributed to tetramethylsilane.

In a control experiment the reaction was performed under identical conditions, but in the absence of $\mathrm{NiCl}_{2}\left(\mathrm{PPh}_{3}\right)_{2}$. The solvent was removed by distillation. The distillate was analyzed by GC-MS (GC temperature, $45^{\circ} \mathrm{C}$; MS electron beam energy, $11 \mathrm{eV}$ ). The intensity of the peak at $m / z 88$ was less than onetenth of that observed in the previous experiment.

Acknowledgment. We thank the National Science Council of the Republic of China and the Croucher Foundation of Hong Kong for financial support.

Supplementary Material Available: Physical properties of, and spectroscopic data on, $7 a-g$ and ${ }^{1} \mathrm{H}$ NMR spectra of 9,23 , and $32 a-j$ (13 pages). Ordering information is given on any current masthead page.

(45) Sauer, J. C. J. Am. Chem. Soc. 1957, 79, 5314. 